Dr. sc. Zoran Šinković, docent

Pravnog fakulteta Sveučilišta u Splitu

Luka Pribisalić, asistent

Pravnog fakulteta Sveučilišta u Splitu

\title{
POREZ NA DOBIT U KONTEKSTU PRAVA EUROPSKE UNIJE
}

\author{
UDK: 336 (4) \\ Primljeno: listopad 2016. \\ Pregledni rad
}

Porez na dobit vrlo je važan porezni oblik u kontekstu prava Europske unije. Stoga je doneseno nekoliko Smjernica vezanih za oporezivanje dobiti. Europska komisija 25. listopada 2016. godine donijela je prijedlog Smjernice o zajedničkoj osnovici poreza na dobit (CCCTB). Ovaj prijedlog je obuhvaćen područjem primjene članka 115. Ugovora o funkcioniranju Europske unije. Tekstom se propisuje da mjere za usklađivanje u okviru toga članka neposredno utječu na uspostavu i funkcioniranje unutarnjeg tržišta. Inicijativa CCCTB-a ponovno je pokrenuta zbog olakšavanja poslovanja unutar Europske unije podvrgavanjem poreznih obveznika jedinstvenom pravilniku, u pogledu zakonodavstva o oporezivanju dobiti poduzeća, koji će se primjenjivati diljem unutarnjeg tržišta, te zbog osiguranja izdržljivosti i otpornosti sustava na agresivno porezno planiranje. Oba cilja imaju odlučujući i izravan utjecaj na unutarnje tržište upravo zato što im je svrha iskorjenjivanje poremećaja u njegovu funkcioniranju.

Ključne riječi: Europska unija, porez na dobit, konsolidirana porezna osnovica

\section{UVOD}

Formalni razlog za oporezivanje dobiti trgovačkih društava nalazi se u činjenici da trgovačka društva imaju status pravne osobe, pa su stoga, kao i fizičke osobe, obvezne plaćati svoj porez na dohodak. Zatim, u teoriji je prisutno obrazloženje da je porez na dobit cijena koju se plaća za povlasticu ograničene odgovornosti vlasnika trgovačkih društava (dioničkih društava i društava s ograničenom odgovornošću). Nadalje, porez na dobit neki teoretičari smatraju plaćanjem za korištenje javnih dobara (npr. objekata infrastrukture) koja trgovačka društva koriste u svom poslovanju, a čije bi korištenje, bez poreza na dobit, zapravo značilo smanjenje troškova poslovanja na teret države, tj. onih koji snose teret raznih poreza iz kojih se ta infrastruktura financira. Svi ovi razlozi u novijoj su teoriji ocijenjeni kao teorijski slabi. Pa ipak, formulirani su i uvjerljiviji argumenti za postojanje poreza na dobit. To su sljedeći argumenti: 
1) porez na dobit je instrument koji upotpunjuje djelovanje poreza na dohodak fizičkih osoba te istovremeno sprečava izbjegavanje porezne obveze. Naime, oporezivanje raspodijeljene dobiti moglo bi se izbjeći naprosto neraspodjeljivanjem dobiti koja bi u cijelosti bila zadržana u trgovačkom društvu i npr. reinvestirana. Na taj način, vrijednost imovine vlasnika dionica ili udjela bi se povećala, čime bi on ostvario kapitalne dobitke. Njihovo oporezivanje porezni obveznik bi, kroz odgodu njihove isplate tj. kroz njihovo zadržavanje u trgovačkom društvu, mogao odgađati do trenutka koji on ocijeni najpogodnijim. Pri tome još jednom treba skrenuti pažnju na činjenicu da je «odgođeni porez = ušteđeni porez»;

2) porezom na dobit osigurava se oporezivanje onog dijela neraspodijeljene dobiti koji po osnovi njihovih ulaganja pripada dioničarima ili vlasnicima udjela koji su nerezidentni porezni obveznici;

3) porez na dobit može se koristiti kao učinkovito sredstvo državne intervencije, tj. državne stabilizacijske i strukturalne politike; ${ }^{1}$

4) međunarodna su motrišta oporezivanja dobiti i kapitalnih dobitaka trgovačkih društava zanimljiva sa stajališta osnivanja novih trgovačkih društava i novih investicija u druge zemlje. Kapital traži gdje je najpovoljnije investirati i gdje je najveća stopa povrata kapitalnih ulaganja. Da bi se utvrdilo gdje je najisplativije investirati, pronalaze se razne metode pomoću kojih vrednujemo gdje je najisplativije uložiti kapital, odnosno gdje je najisplativije osnovati trgovačko društvo i prebaciti svoje poslovanje. $^{2}$

Činjenica je kako roba i usluge, danas imaju veću slobodu kretanja među državama članicama Europske unije nego ikad prije, a način na koji je uređen neki sustav oporezivanja dobiti trgovačkih društava može potaknuti seljenje kapitala iz razvijenijih u manje razvijene tržišne ekonomije. Sve to utječe na promjene u ekonomskom okruženju država članica i odražava se na promjene u fiskalnim, ali i ostalim vrstama politika, što se pak odražava na blagostanje u pojedinim državama članicama. ${ }^{3}$

Kako bi se ostvario cilj pravednijeg i učinkovitijeg oporezivanja i djelotvorno suzbilo izbjegavanje poreza na dobit, Europska unija mora usvojiti novi pristup oporezivanju dobiti trgovačkih društava.

Taj bi se pristup trebao temeljiti na sljedećim ciljevima:

1) ponovno uspostaviti veze između oporezivanja i mjesta obavljanja gospodarske aktivnosti;

1 Podrobnije vidjeti u: Bo. Jelčić, O. Lončarić-Horvat, J. Šimović, H. Arbutina, N. Mijatović, Financijsko pravo i financijska znanost, Narodne novine, Zagreb, 2008., str. 340-342.

2 Usporediti: D. Roller, „Oporezivanje poduzeća u uvjetima nove globalne ekonomije“, Zbornik radova s međunarodnog znanstvenog skupa „Uloga države u socio-ekonomskom razvoju nacionalnog gospodarstva" u povodu 80. godišnjice života prof. emeritusa Božidara Jelčića, Visoka poslovna škola Libertas, Zagreb, 2010., str. 334.

N. Sokol-Knjaz, „Porezna konkurencija kao čimbenik mobilnosti kapitala u Europskoj uniji“, Zbornik radova s međunarodnog znanstvenog skupa „Uloga... o. c., str. 362. 
2) državama članicama omogućiti točno vrednovanje aktivnosti trgovačkih društava u njihovoj nadležnosti;

3) stvoriti konkurentan i za rast poticajan sustav oporezivanja dobiti trgovačkih društava u Europskoj uniji čime bi se, u skladu s preporukama europskog semestra, povećala otpornost poslovnog sektora;

4) štititi jedinstveno tržište i osigurati snažan pristup Europskoj uniji vanjskim pitanjima oporezivanja dobiti trgovačkih društava, uključujući mjere za provedbu OECD-ova Projekta za suzbijanje erozije porezne osnovice i premještanja dobiti (BEPS) radi rješavanja problema s nekooperativnim poreznim jurisdikcijama i veće transparentnosti oporezivanja. ${ }^{4}$

\section{PRIKAZ SMJERNICA EUROPSKE UNIJE U PODRUČJU OPOREZIVANJA DOBITI}

O prijedlozima o usklađivanju poreza na dobit raspravlja se već više od pedeset godina (izvješće Neumarka iz 1962. godine, izvješće Van den Tempela iz 1970. godine, prijedlog Smjernice za usklađivanje poreznih stopa od 45\% do 55\% iz 1975. godine). Komisija je 1980. godine zaključila da je taj pokušaj usklađivanja vjerojatno bezizgledan te se usredotočila na mjere za dovršenje uspostave unutarnjeg tržišta. ${ }^{56}$

Povijest upozorava na trnovit put usklađivanja sustava oporezivanja dobiti u Europskoj uniji. Obilježen je većim brojem neuspjeha uz rijetke trenutke dosezanja konsenzusa svih članica o određenim elementima toga poreznog oblika što ga je radi djelovanja unutarnjeg tržišta nužno uskladiti. Pravni temelj usklađivanja poreza na dobit jest čl. 115. Ugovora o funkcioniranju Europske unije što zapravo svakoj članici ostavlja pravo veta. ${ }^{7}$

No, i drugi su aspekti sustava oporezivanja dohotka/dobiti pod utjecajem prava Europske unije i to u dijelu u kojemu krše zabranu diskriminacije domaćih i proizvoda drugih država članica (čl. 110. Ugovora o funkcioniranju Europske unije) ili ograničavaju temeljne tržišne slobode. Bogata praksa Europskog suda pravde (Suda Europske unije) posljednjih tridesetak godina, počevši s presudom u predmetu Avoir Fiscal iz 1986. godine pokazuje razmjere mogućih povreda prava Europske unije radi primjene odredba nacionalnog prava u vezi s porezom na dobit. ${ }^{8}$

Drugim riječima, harmonizacija poreznih sustava država članica Europske unije izvjesno je važan čimbenik uspostave i djelovanja jedinstvenog tržišta, a

4 Podrobnije vidjeti mrežnu stranicu: http://ec.europa.eu/fair-taxation.

5 D. Birk, M. Desens, H. Tappe, Steuerrecht 18. neu bearbeitete Auflage, C. F. Müller, Heidelberg, 2015., str. 71.-74.

6 A. P. Lier, (ed.), Tax and Legal Aspects of EC Harmonisation, Kluwer Law \&Taxation Publishers, Deventer, Boston, 1993.

7 S. Gadžo, „Oporezivanje dobiti u Europskoj uniji: novi Akcijski plan Europske komisije“, Porezni vjesnik, br. 11., Ministarstvo financija, Porezna uprava, Središnji ured, Zagreb, 2015., str. 103.

8 Ibid. 
u tom kontekstu jest i harmonizacija sustava oporezivanja dobiti. Međutim, bez obzira na važnost, trebalo je proći dugo vremena od pojave inicijativa i koncepcija harmonizacije do njihove realizacije (barem u određenom opsegu).

Prijedlozi dviju Smjernica - čiji su sadržaj bila rješenja nekih problema u području oporezivanja raspodijeljene dobiti i transformacija trgovačkih društava bili su formulirani još 1969. godine, a obje Smjernice usvojene su tek 1990. godine. ${ }^{9}$ Skraćeno te se Smjernice u literaturi uobičajeno nazivaju Smjernica o matičnom i zavisnom trgovačkom društvu (Parent-Subsidiary Directive) i Smjernica o spajanjima (Merger Directive). ${ }^{10}$

U 1990. godini Komisija je nakon ponovnog razmatranja problematike usklađivanja poreza na dobit, izdala dokument („Communication“) u kojem je utvrdila svoj revidirani pristup izravnim porezima.

Izvorni, široko zasnovani planovi su odbačeni u korist usredotočenja na prekogranične transakcije i u lipnju 1990. godine usvojene su mjere u vezi sa:

- zajedničkim sustavom oporezivanja primjenjivih na tretman dividendi koje se isplaćuju između matičnog trgovačkog društva (društva-roditelja) i zavisnog trgovačkog društva koje se nalazi u drugoj državi članici (direktiva o matičnom i zavisnom trgovačkom društvu), i

- zajedničkim pristupom oporezivanja spajanja, podjela, prijenosa imovine i razmjene dionica, koje se transakcije tiču trgovačkih društava različitih država članica (Smjernica o spajanjima). ${ }^{11}$

9 H. Arbutina, ,Jedan napor za postignuće harmonizacije oporezivanja dobiti u Europskoj uniji: Direktiva o matičnom i zavisnom društvu“, Godišnjak Akademije pravnih znanosti, br. 1., Zagreb, 2010., str. 73-92.

10 Puni nazivi ovih propisa su: Smjernica Vijeća 90/434/EEZ, Smjernica Vijeća 2005/19/EZ, Smjernica Vijeća 2006/98/EZ, Smjernica Vijeća 2009/133/EZ o zajedničkom sustavu oporezivanja primjenjivom na spajanja, podjele, prijenos imovine i razmjenu udjela, s obzirom na trgovačka društva različitih državačlanica (Council Directive 90/434/EEC, Council Directive 2005/19/EC, Council Directive 2006/98/EC, Council Directive 2009/133/EC on the Common System of Taxation Applicable to Mergers, Divisions, Transfers of Assests and Exchanges of Shares Concerning Companies of Different Member States) i Smjernica Vijeća 90/435/EEZ, Smjernica Vijeća 2003/123/EZ, Smjernica Vijeća 2006/98/EZ, Smjernica Vijeća 2011/96/EZ, Smjernica Vijeća 2014/86/EZ, Smjernica Vijeća 2015/121/EZ o zajedničkom sustavu oporezivanja primjenjivom u slučaju matičnih i zavisnih trgovačkih društava različitih država-članica (Council Directive 90/435/EEC, Council Directive 2003/123/EC, Council Directive 2006/98/EC, Council Directive 2011/96/EC, Council Directive 2014/86 EC, Council Directive 2015/121/EC on the Common System of Taxation Applicable in the Case of Parent Companies and Subsidiaries of Different Member States).

11 L. Cerioni, EU Corporate Law and Company Tax Law, Edward Elgar Publishing, UK, 2007. (prvo poglavlje u knjizi). 


\section{1. Isplata dividendi i udjela u dobiti između matičnih društava i povezanih društava iz različitih država članica prema Smjernici o matičnom i zavisnom trgovačkom društvu}

Pravno gledano, cilj je Smjernice o matičnom i zavisnom društvu - propisati jedinstveni porezno-pravni okvir za jedan segment kretanja kapitala unutar Europske unije. Radi se o isplatama raspodijeljene dobiti (dividende) koju zavisna trgovačka društva država članica vrše svojim matičnim društvima u drugim državama članicama Europske unije. ${ }^{12}$ Kako ne bi dolazilo do dvostrukog opterećenja u pogledu dividendi isplaćivanih unutar Europske unije, Smjernica uklanja element dvostrukog opterećenja tako što državama člancima propisuje: a) ukidanje poreza po odbitku na dividende isplaćene matičnom društvu unutar Europske unije i b) neoporezivanje dividendi koje matično društvo primi od zavisnog društva, također unutar Europske unije. ${ }^{13}$

Porez po odbitku na dividende i udjele u dobiti ne plaća se kada dividende ili udjele u dobiti isplaćuje kvalificirano društvo drugom kvalificiranom društvu. Oba društva (matica i zavisno društvo) moraju ispunjavati određene uvjete za primjenu oslobođenja. Naime, isplatitelj i primatelj dividende ili udjela u dobiti moraju biti kvalificirana društva:

1) društvo koje ima jedan od oblika na koji se primjenjuje zajednički sustav oporezivanja vrijedeći za matična društva i povezana društva iz različitih država članica Europske unije, drugim riječima trgovačko društvo mora imati jedan od statusnih oblika propisanih Dodatkom (Aneksom) kao sastavnim dijelom Smjernice odnosno Dodatkom E koji je sastavni dio Pravilnika o porezu na dobit; ${ }^{14}$

2) društvo koje je rezident države članice Europske unije u skladu s pravom te države i ne odnosi se na rezidente izvan Europske unije prema međunarodnim ugovorima o izbjegavanju dvostrukog oporezivanja, zaključenih s državama nečlanicama;

3) društvo koje mora biti obveznik jednog od u podstavku c) čl. 2. Smjernice odnosno Dodatka F Pravilnika o porezu na dobit navedenih poreza ili poreza koji bi mogao zamijeniti navedene poreze, bez mogućnosti da od tako određenih poreza bude izuzeto. ${ }^{15}$ Ovo pravilo se osobito odnosi na pojedina društva osoba, koja imaju

12 H. Arbutina, Jedan napor... o. c., str. 73-92.

13 Implementation of the amended Parent-Subsidiary Directive, A study covering the 27 European Union Member States, Ernst\&Young, 2009. (PDF), dostupno na mrežnoj stranici: www. ey.com>Publication>VWLUASsets, https://www.world.tax.

14 Narodne novine, br. 95/05, 133/07, 156/08, 146/09, 123/10, 137/11, 61/12, 146/12, 160/13, 12/14, $157 / 14,137 / 15$.

15 U skladu s ovako definiranim kriterijima, Europski sud pravde (Sud Europske unije) u predmetu Gaz de France presudio je (par. 43) da subjekti koji nisu izričito navedeni u Aneksu Smjernice nisu obuhvaćeni njome, nije prihvatljivo proširenje obuhvata Smjernice temeljem analogije na Aneksom nespomenute subjekte. Podrobnije vidjeti u: Predmet C-247/08, Gaz de France - Berliner Investissement SA v. Bundeszentralamt für Steuern, [2009] ECR I-00000. 
pravo izbora oporezivanja porezom na dobit, kao i na društva koja su subjekti poreza na dobit, ali za koja vrijedi subjektivno oslobođenje.

Status matičnog društva postignut je ako od 1. siječnja 2009. godine postoji minimalni vlasnički udio od $10 \%$ u zavisnom društvu. ${ }^{16}$

Drugim riječima primatelj dividende ili udjela u dobiti mora imati: a) najmanje $10 \%$ udjela u kapitalu društva koje isplaćuje dividendu ili udio u dobiti (udjeli ne moraju biti u neposrednom vlasništvu, uvjet je zadovoljen i kod isplata dividende ili udjela stalnoj poslovnoj jedinici matice ili ortaštvu, ako se dividenda ili udio u dobiti može izravno pripisati osobama koje čine ortaštvo i koje istovremeno ispunjavaju gore navedene uvjete kao kvalificirana društva), b) postotak udjela od najmanje $10 \%$ primatelj dividende ili udjela u dobiti mora imati u neprekidnom razdoblju od 24 mjeseca (oslobođenje se može koristiti i u slučaju isplate predujma dividende ili udjela u dobiti, a prije ispunjenja roka od 24 mjeseca, ako rok naknadno bude ispunjen), ${ }^{17}{ }^{18} \mathrm{c}$ ) u trenutku isplate mora postojati dokaz da primatelj dividende ili udjela u dobiti ima jedan od oblika trgovačkih društava navedenih u poreznopravnim propisima svake države članice Europske unije u skladu s odredbama Smjernice, odnosno to je pitanje regulirano u Republici Hrvatskoj čl. 31. e Zakona o porezu na dobit ${ }^{19}$ i čl. 51. b Pravilnika o porezu na dobit. ${ }^{20}{ }^{21}$

Gore navedeni uvjeti vezani uz oslobođenje plaćanja poreza po odbitku na isplate dividendi ili udjela u dobiti ne primjenjuju se ako je razvidno da isplata dividendi ili udjela u dobiti za glavni cilj ili jedan od glavnih ciljeva ima utaju poreza ili izbjegavanje poreza. ${ }^{22}$

16 Podrobnije vidjeti u: C. Brokelind, „,The Proposed Amendments to the Parent-Subsidiary Directive: Some Progress?“" European Taxation, br. 12/2003., str. 452.

17 Spojeni predmeti C-283/94, C-291/94 i C-292/94 (Denkavit International BV,VITIC Amsterdam BV i Voormmer BV v. Bundesamt für Finanzen).

18 Povlastice propisane Smjernicom naročito ne treba primjenjivati ako matično društvo nije vlasnik svog udjela u zavisnom društvu tijekom neprekinutog razdoblja od najmanje dvije godine. Neke države članice iskoristile su ovu mogućnost, druge su se opredijelile za obvezno razdoblje zadržavanja vlasničkog udjela u trajanju od godinu dana, treće nisu propisale minimalno zahtijevano razdoblje vlasništva nad udjelom. Neke države članice uključile su i druge protuevazijske odredbe u svoje domaće pravo.

19 Narodne novine, br. 177/04, 90/05, 57/06, 146/08, 80/10, 22/12, 148/13, 143/14, 50/16.

20 Vidjeti u: Dodatak E Pravilnika o porezu na dobit.

21 Gore navedeni uvjeti vezani za oslobođenje od poreza po odbitku odnose se i na isplate dividendi ili udjela u dobiti stalnim poslovnim jedinicama matice društva isplatitelja, iako to Zakonom o porezu na dobit i Pravilnikom o porezu na dobit izričito nije propisano.

22 Potrebno je spomenuti da čl. 4 st. 1. toč. 1. Smjernice ima učinak i za hrvatska matična društva koja drže udjele u zavisnim društvima sa sjedištem na teritoriju Europske unije. Ista odredba je implementirana u čl. 6. st. 1. toč. 1. Zakona o porezu na dobit, prema kojem se porezna osnovica poreznog obveznika smanjuje (između ostalog) za prihode od dividendi i udjela u dobiti - bez obzira na (i) visinu udjela u kapitalu, (ii) rok držanja tog udjela drugog društva koje isplaćuje dividendu ili udio u dobiti i (iii) mjesto sjedišta drugog društva (društva država nečlanica Europske unije nisu isključena od ovog oslobođenja). Iako Smjernica predviđa mogućnost ograničenja u priznanju troškova držanja udjela u zavisnom društvu, takvo ograničenje nije preuzeto u hrvatsko zakonodavstvo, te su troškovi nastali za nabavku, držanje i prodaju udjela u zavisnim društvima porezno priznati rashod za hrvatska matična društva. 


\section{2. Oporezivanje isplata kamata $i$ autorskih naknada između povezanih društava različitih država članica prema Smjernici o matičnom i zavisnom trgovačkom društvu}

Mogućnost isplate kamata i autorskih naknada bez poreza po odbitku uređena je čl. 31.a - 31. d Zakona o porezu na dobit, odnosno čl. 51.a Pravilnika o porezu na dobit. Prema odredbi čl. 31.b Zakona o porezu na dobit, porez po odbitku se ne plaća na isplate kamata i autorskih naknada ako je riječ o transakcijama između (kvalificiranih) povezanih društava iz različitih država članica Europske unije. Za oslobođenje od plaćanja poreza po odbitku moraju biti zadovoljeni određeni preduvjeti pa trgovačko društvo (isplatitelj i stvarni korisnik) ${ }^{23}$ mora biti:

1) društvo koje ima jedan od oblika za koje se koristi zajednički sustav oporezivanja u svezi s plaćanjem kamata i autorskih naknada, koji vrijedi za povezane osobe iz različitih država članica Europske unije prema popisu u Dodatku C, sastavnom dijelu Pravilnika o porezu na dobit;

2) rezident u državi članici Europske unije u skladu s pravom te države i ne smatra se rezidentom izvan Europske unije u skladu s međunarodnim ugovorom o izbjegavanju dvostrukog oporezivanja, sklopljenog s državom nečlanicom Europske Unije;

3) porezni obveznik jednog od poreza u svezi kojeg se koristi zajednički sustav oporezivanja u svezi s plaćanjem kamata i autorskih naknada koji vrijedi za povezane osobe iz različitih država članica Europske unije, prema popisu u Dodatku D Pravilnika o porezu na dobit. Poreznim obveznikom ne smatra se društvo subjektivno oslobođeno takvog poreza (čl. 31.a Zakona o porezu na dobit). ${ }^{24}$

Gore navedeni uvjeti vezani za oslobađanje od poreza po odbitku odnose se i na isplate kamata i autorskih naknada stalnim poslovnim jedinicama, kako je to

23 Trgovačko društvo smatra se povezanim s drugim društvom ako: prvo trgovačko društvo (isplatitelj) ima izravni minimalni udjel od $25 \%$ kapitala drugoga trgovačkog društva (stvarnog korisnika) - matica je isplatitelj naknade, ili drugo trgovačko društvo (stvarni korisnik) ima izravni minimalni udjel od $25 \%$ kapitala prvoga trgovačkog društva (isplatitelja) - zavisno društvo je isplatitelj, ili treće trgovačko društvo ima izravni minimalni udjel od $25 \%$ kapitala prvog (isplatitelja) i drugoga trgovačkog društva (stvarnog korisnika), a pri tome se radi o udjelima između društava iz država članica Europske unije - isplate između povezanih društava ,sestara“.

Povezanost udjelima mora trajati neprekidno najmanje 24 mjeseca. Ako gore navedeni uvjeti nisu ispunjeni, ne dolazi do oslobođenja od plaćanja poreza po odbitku prema odredbama čl. 31.a st. 4. Zakona o porezu na dobit.

${ }^{24}$ Uz to, važno je znati da se predmetna oslobađanja primjenjuju samo u slučaju da stvarni korisnik ispunjava gore navedene uvjete, a s ciljem sprečavanja zlouporabe Smjernice (,directive shopping“"). Društvo je stvarni korisnik samo ako prima te uplate u svoju korist, što znači da nije posrednik, poput agenta, opunomoćenika ili ovlaštenog potpisnika za neku drugu osobu. U skladu s čl. 31.c st. 3. Zakona o porezu na dobit, stalna poslovna jedinica može biti korisnik kamata ili autorskih naknada samo ako se kamate i autorske naknade stvarno povezuju s tom poslovnom jedinicom te ako kamate i autorske naknade o kojima je riječ čine prihod prema kojem je poslovna jedinica obveznik nekog od poreza za koji se primjenjuje sustav zajedničkog oporezivanja na isplate kamata i autorskih naknada. Potrebno je spomenuti da neispunjavanje uvjeta iz čl. 31.a. do 31.d Zakona o porezu na dobit ne isključuje primjenu Ugovora o izbjegavanju dvostrukog oporezivanja, ako su odredbe takvog Ugovora povoljnije za poreznog obveznika. 
navedeno čl. 31.b st. 1. Zakona o porezu na dobit. Stalnom poslovnom jedinicom nekog društva smatra se stalno mjesto poslovanja u jednoj državi članici Europske unije putem kojega trgovačka društva druge članice Europske unije u cijelosti ili djelomično obavljaju svoje poslovanje.

\section{3. Spajanje, podjela, djelomična podjela, prijenos imovine i zamjena dionica trgovačkih društava iz različitih država članica prema Smjernici o spajanjima}

Prekogranične transakcije poduzete s ciljem različitih vrsta transformacije trgovačkih društava ili promjena u njihovoj imovini, mogu imati određene posljedice. Te porezne posljedice mogu utjecati na planirane transakcije, čak do te mjere da dovedu do odustajanja od njih. Kao što je već rečeno Vijeće Europskih zajednica je 1990. godine donijelo Smjernicu o spajanjima, propis kojemu je cilj uklanjanje poreznih prepreka prekograničnim transakcijama. ${ }^{25} 26$

Negativne porezne posljedice koje trebaju biti uklonjene djelovanjem Smjernice su slijedeće: a) oporezivanje nerealiziranog kapitalnog dobitka, b) oporezivanje rezerviranja i c) gubitak prava na porezno priznati gubitak. ${ }^{27}$

Cilj Smjernice jest ukloniti te prepreke ako se spajanje, dioba ili reorganizacija odvijaju samo između trgovačkih društava zemalja članica. Smjernicom propisani način postizanja cilja jest odgoda obveze plaćanja poreza i uobičajeno, do prodaje imovine trećoj strani. ${ }^{28} 29$

Primjena Smjernice moguća je uz zadovoljenje određenih uvjeta i primjenjuje se samo za određene subjekte. Trgovačkim društvom rezidentom države članice Europske unije o kojemu je ovdje riječ, smatra se društvo koje ispunjava sljedeće uvjete, a u skladu s čl. 20.a st. 1. Zakona o porezu na dobit:

1) ima jedan od oblika za koji se primjenjuje zajednički sustav oporezivanja koji vrijedi za spajanja, podjelu, djelomičnu podjelu, prijenos imovine i zamjenu dionica društava iz različitih država članica Europske unije, te za prijenos sjedišta europskog društva (dalje: SE) ili europske zadruge (dalje: SCE), a prema popisu u Dodatku A Pravilnika o porezu na dobit;

25 Bo. Jelčić, O. Lončarić-Horvat, J. Šimović, H. Arbutina, N. Mijatović, Financijsko pravo... o. c., str. 364

26 https://www.ogier.com, https://ideas.repec.org >btx >wpaper.

27 Bo. Jelčić, O. Lončarić-Horvat, J. Šimović, H. Arbutina, N. Mijatović, Financijsko pravo... o. c., str. 364-365.

28 Ibid., str. 366.

29 Prekogranične mjere prestrukturiranja (spajanje, podjela, djelomična podjela, prijenos imovine, prijenos sjedišta i zamjena dionica) unutar Europske unije mogu sa sobom nositi i latentno oporezivanje skrivenih pričuva prenijete imovine ili dionica. U usporedbi s nacionalnim prestrukturiranjem koje je u većini država neutralno za oporezivanje, moglo bi doći do nejednakog postupanja prekograničnih prestrukturiranja. Prvi cilj Smjernice jest ukidanje nejednakosti putem porezne neutralnosti prekograničnih prestrukturiranja. Sljedeći ciljevi Smjernice jesu: 1) zaštita fiskalnih interesa država članica i 2) poticanje prekograničnih aktivnosti, osobito prestrukturiranja unutar Europske unije. 
2) rezident je države članice Europske unije u skladu s pravom te države,

3) obveznik je jednog od poreza za koji se primjenjuje zajednički sustav oporezivanja koji vrijedi za spajanja, podjelu, djelomičnu podjelu, prijenos imovine i zamjenu dionica društava iz različitih država članica Europske unije, te za prijenos sjedišta SE ili SCE između država članica, a prema popisu u Dodatku B Pravilnika o porezu na dobit.

Smjernica određuje nekoliko vrsta transakcija na koje odredbe o odgodi poreza mogu biti primijenjene. Države članice mogu, naravno, propisati i značajnije pogodnosti. Transakcije obuhvaćene odredbama Smjernice jesu:

1) spajanje i podjela (uključujući djelomičnu podjelu) - prava spajanja tj. slučajevi spajanja djelatnosti dvaju ili više trgovačkih društava iz različitih država članica, pri čemu ta društva postaju jedan subjekt, odnosno podjele, tj. obratno od spajanja, slučajevi prijenosa cjelokupne imovine trgovačkih društava koja su prestala postojati a da pri tome nisu likvidirana, na dva ili više trgovačkih društava u više od jedne države članice. Prestanak bez likvidacije moguć je ako su sva imovina i sve obveze trgovačkog društva preneseni na drugo trgovačko društvo i ako to drugo trgovačko društvo preuzme sva prava i obveze preostaloga trgovačkog društva kao u slučaju spajanja. ${ }^{30}$

Ako se u prenesenom društvu na dan spajanja, podjele ili djelomične podjele ostvaruje dobit ili gubitak, koji se odnosi na prenesenu imovinu i obveze, dobit se ne oporezuje, a gubitak se ne priznaje i to na način da porezni obveznik u poreznom razdoblju koje prethodi statusnoj promjeni prema čl. 19. Zakona o porezu na dobit iskazuje skrivene pričuve, koje se ne oporezuju u trenutku spajanja, podjele ili djelomične podjele. Na kraju spajanja ili podjele društvo preuzimatelj tajnih pričuva mora imati istu poreznu situaciju kao i prenositelj tajnih pričuva. Kasnije (eventualno) oporezivanje tajnih pričuva mora biti osigurano i to na način da se tajne pričuve pripisuju stalnoj poslovnoj jedinici društva preuzimatelja u državi članici društva koje prijenos obavlja i ima utjecaj na dobit ili gubitak pri obračunu poreza.

Ako spajanje, podjela, djelomična podjela ili prijenos imovine uključuje stalnu poslovnu jedinicu prenesenog društva koja se nalazi u drugoj državi članici, država članica u kojoj preneseno društvo ima sjedište neće oporezivati tu poslovnu jedinicu. Preneseno društvo može u dobitak uključiti gubitke poslovne jedinice koji nisu nadoknađeni. Odredbe čl. 20.a do 20.o Zakona o porezu na dobit uglavnom se odnose na neoporezivanje, ako se nastavlja poslovna aktivnost poslovne jedinice $u$ državi u kojoj se i do sada obavljala djelatnost.

2) Prijenosa imovine, tj. slučajevi prijenosa cjelokupnog poslovanja ili jedne, ili više poslovnih jedinica na svoje matično društvo, ili na trgovačko društvo u drugoj državi članici, u zamjenu za udjele u društvu na koje se poslovanje ili poslovna jedinica prenose.

30 H. Arbutina i K. Ott, Porezni leksikon s višejezičnim rječnikom, Institut za javne financije, Zagreb, 1999., str. 107. 
Porezni status prenesene imovine uređen je čl. 20.c - 20.f. Zakona o porezu na dobit, te čl. 41.b - 41.e Pravilnika o porezu na dobit. Preduvjet primjene ovih odredbi jest da se prenose sve, više ili samo jedna gospodarska cjelina društva. $\mathrm{Na}$ razini društva, koje prenosi imovinu i društva preuzimatelja, vrijede isti preduvjeti kao i kod spajanja, podjele ili djelomične podjele, tj. ne smije doći do oporezivanja dobiti (a gubitak se ne priznaje) koja je ostvarena kod prenesene imovine, ukoliko se ona pripisuje stalnoj poslovnoj jedinici društva preuzimatelja u državi članici društva koje prijenos obavlja.

3) Zamjena dionica ili udjela - u ovom slučaju radi se o operaciji kojom jedno trgovačko društvo stječe većinu udjela u drugom društvu od vlasnika udjela u tom drugom društvu. Dakle, društvo u kojemu je udjele steklo društvo stjecatelj postaje zavisno od društva stjecatelja, zauzvrat, vlasnici udjela koje je steklo društvo stjecatelj postaju dioničari društva stjecatelja.

Odredbama čl. 20. 1 st. 1. Zakona o porezu na dobit utvrđeno je da se kapitalni dobici pri zamjeni dionica i udjela ne oporezuju. Analogno tome se ni ostvareni gubici u takvim transakcijama ne priznaju za svrhe oporezivanja. Odredbe o zamjeni dionica i udjela primjenjuju se na oporezivanje transakcija u kojima su društvo stjecatelj i preuzeto društvo hrvatski rezident i/ili rezident druge države članice Europske unije i ako je društvo hrvatski rezident, ili ako nije hrvatski rezident a imatelj je vrijednosnih papira preuzetog društva i društva stjecatelja putem poslovne jedinice u Republici Hrvatskoj.

Odredbe o zamjeni dionica ili udjela imaju zapravo utjecaj na oporezivanje članova društava. Član društva procjenjuje vrijednosne papire preuzetog društva prema poreznoj vrijednosti koju su vrijednosni papiri imali kod preuzetog društva u trenutku zamjene. Ako vrijednosne papire ne procjenjuje po toj vrijednosti, odredbe Smjernice (i Zakona o porezu na dobit) se ne primjenjuju. S druge strane, društvo stjecatelj primljene vrijednosne papire preuzetog društva procjenjuje prema njihovoj fer vrijednosti na dan zamjene. Eventualna dobit iz kasnije prodaje preuzetih dionica odnosno udjela, oporeziva je u skladu s čl. 5. st. 4. Zakona o porezu na dobit.

4) Kod prijenosa sjedišta SE ili SCE - u slučaju prijenosa (SE) ili (SCE) iz Republike Hrvatske u drugu članicu Europske unije i iz druge članice Europske unije u Republiku Hrvatsku, takav prijenos ne dovodi do oporezivanja dobitaka (čl. 20.n Zakona o porezu na dobit) u državi članici iz koje je sjedište preneseno, ostvarenih od imovine i obveza SE ili SCE, pod uvjetom da ta društva ostaju povezana sa stalnom poslovnom jedinicom toga društva u državi članici iz koje je obavljen prijenos sjedišta. Međutim, takva se odredba, prema čl. 41.k Pravilnika o porezu na dobit, primjenjuje samo onda kada SE ili SCE izračuna novu amortizaciju i dobitak ili gubitak povezan s imovinom i obvezama, koje ostaju stvarno povezane s tom stalnom poslovnom jedinicom u Republici Hrvatskoj. Kada SE ili SCE ima pravo na novu amortizaciju i dobitak ili gubitak u vezi s imovinom i obvezama koje ostaju u odnosnoj državi članici a izračunavaju se na drukčiji način, tada se odredbe o neoporezivanju ne odnose na imovinu i obveze za koje se primjenjuje ta drukčija 
amortizacija, odnosno utvrđivanje dobitka ili gubitka (čl. 41.k st. 3. Pravilnika o porezu na dobit).

Stalna poslovna jedinica sa sjedištem u državi iz koje je preneseno sjedište SE ili SCE može koristiti neiskorištene porezne gubitke SE-a ili SCE-a, ako je u usporednim okolnostima takav prijenos dopušten i drugim društvima. ${ }^{31}$

\section{ZNAČAJ SUDSKE PRAKSE I ULOGA EUROPSKE KOMISIJE U PRIMJENI PROPISA O OPOREZIVANJU DOBITI}

Propise o izravnim porezima Europske unije možemo podijeliti na primarno, sekundarno i supsidijarno pravo Europske unije: a) izvore primarnog prava Europske unije čine uglavnom osnivački ugovori Europske zajednice s kasnijim izmjenama i dopunama kao i Ugovor o osnivanju Europske unije s izmjenama, b) izvori sekundarnog prava sastoje se od dijela prava koje proizlazi iz primarnog prava. U izvore sekundarnog prava ulaze jednostrani pravni akti (npr. uredbe i smjernice), kao i bilateralni (međunarodni) ugovori, c) izvori supsidijarnog prava sastoje se od dijela prava koje ne proizlazi iz primarnog prava. Ovdje se radi pored sudske prakse Europskih sudova - o običajnom pravu država članica i općim pravnim načelima.

Europski sud pravde (engl. Court of Justice) jedan je od sudova unutar Suda Europske unije, institucija Europske unije koja tumači odredbe osnivačkih ugovora i rješava sporove po tužbama država članica i građana čija su prava povrijeđena nekom od odluka tijela Unije. Europski sud pravde (Sud Europske unije) je osnovan 1952. godine i ima sjedište u Luxembourgu. ${ }^{32}$

31 O harmonizaciji izravnih poreza podrobnije vidjeti mrežne stranice: http://www.savjetovanje.eu/ aktualno/harmonizacija-direktnih-poreza-republike-hrvatske-s-propisima-europske-unije/, http://www. europarl.europa.eu/atyourservice/hr/displayFtu.html?ftuId=FTU_5.11.1.html.

32 Također postoji i Europski sud za ljudska prava (engl. European Court of Human Rights, franc. Cour europeenne des Droits de l' Homme) koji je sudska institucija Vijeća Europe, osnovana 1959. godine, za zaštitu prava i sloboda koje se jamče Europskom konvencijom o ljudskim pravima (1950. godine). Sud je postao stalna institucija zaštite ljudskih prava u Europi 1. studenoga 1998. godine, kada je stupio na snagu Protokol 11. Europske konvencije o ljudskim pravima. Prije uvođenja ovog protokola, sudsku funkciju je, pored Suda, obavljala i Europska komisija za ljudska prava (1954. godine). Protokol je ukinuo Komisiju, ali je ona nastavila s radom do 31. listopada 1999. godine radi okončanja tekućih postupaka. U prve tri godine samostalnog postojanja Europskog suda za ljudska prava, broj sporova uvećan je za oko $130 \%$. Inicijalni akt za pokretanje spora pred Sudom jest predstavka (engl. Application). Predstavke su sredstva kojima se traži zaštita u slučaju kršenja ljudskih prava i sloboda od strane države potpisnice Europske konvencije o ljudskim pravima i članice Vijeća Europe. Individualne predstavke Sudu upućuju pojedinci, grupe osoba ili nevladine organizacije, a međudržavne predstavke zemlje članice Vijeća Europe. Predstavke se dostavljaju na posebnom formularu, koji sadrži podatke o Sudu, podnosiocu predstavke, državi koja je prekršila obvezu preuzetu Europskom konvencijom, činjenicama i dokazima kršenja ljudskih prava. Rasprava je pismena, ali Sud može odlučiti da se vodi usmeni postupak radi izvođenja određenih dokaza. Stranka koja nije u stanju snositi troškove postupka ima pravo na besplatnu pravnu pomoć. Besplatnu pravnu pomoć osigurava Sud osobi koja priloži dokaze o nedostatku financijskih sredstava za isplatu sudske naknade. Suđenje se obavlja u sjedištu Suda, u Strasbourgu, s tim što se neke radnje mogu vršiti i izvan sudske zgrade, Strasbourga i Francuske, ukoliko to nalažu potrebe postupka. Presuda postaje pravomoćna ako se stranke odreknu zahtjeva za iznošenje predmeta pred Veliko vijeće ili ako, po proteku roka od tri mjeseca, ne zahtijevaju da se predmet uputi Velikom vijeću. Pravomoćna odluka objavljuje se i prosljeđuje Vijeću ministara Vijeća Europe koji provodi nadzor 
Zbog preopterećenosti Suda Europska zajednica 1988. godine osniva Prvostupanjski sud Europskih zajednica (danas Opći sud). Sve do Ugovora iz Nice 2001. godine, ovaj je Sud djelovao kao pridruženo tijelo Europskog suda, a ne kao zaseban sud.

Nadležnosti Suda Europske unije: Sud donosi odluke u postupcima koji su pokrenuti pred njime. Pet najučestalijih vrsta postupaka odnosi se na: a) tumačenje prava (prethodna pitanja) - nacionalni sudovi država članica Europske unije dužni su osigurati pravilnu primjenu prava Europske unije, no sudovi u različitim državama mogu ga različito tumačiti. Ako nacionalni sud ima nedoumice $u$ vezi s tumačenjem ili valjanošću određenog zakonodavnog akta Europske unije, on se može obratiti Sudu za objašnjenje, isti se mehanizam može upotrebljavati za utvrđivanje usklađenosti nacionalnog zakona ili prakse s pravom Europske unije, b) provedbu prava (tužbe zbog povrede prava) - ovi se postupci pokreću protiv nacionalnih vlada, ako ne djeluju u skladu s pravom Europske unije. Mogu ih pokrenuti Europska komisija ili druge države članice Europske unije, ako Sud utvrdi da je određena država članica prekršila pravo, ona mora odmah poduzeti mjere da to ispravi. U protivnom se može pokrenuti drugi postupak, u kojem se toj državi može izreći novčana kazna, poništenje pravnih akata Europske unije (tužbe za poništenje). Ako se smatra da se određenim aktom Europske unije krše ugovori o Europskoj uniji ili temeljna prava, vlade država članica Europske unije, Vijeća Europske unije, Europske komisije ili (u nekim slučajevima) Europski parlament, od Suda mogu zatražiti da poništi taj akt, i pojedinci mogu zatražiti od Suda da poništi određeni akt Europske unije koji se izravno odnosi na njih, c) osiguravanje djelovanja Europske unije (tužbe zbog propusta) - Parlament, Vijeće i Komisija dužni su donositi određene odluke u određenim okolnostima, ako to ne učine, vlade država članica Europske unije, druge institucije Europske unije ili (uz određene uvjete) pojedinci ili poduzeća, mogu se obratiti Sudu, d) kažnjavanje institucija Europske unije (tužbe za naknadu štete) - svi pojedinci ili poduzeća koja pretrpe štetu zbog djelovanja ili propusta Europske unije ili njegova osoblja, protiv njih mogu podnijeti tužbu pred Sudom. ${ }^{33}$

Drugim riječima Sud Europske unije tumači pravo Unije radi osiguranja njegove pravilne primjene. Europska unija tako često zahtijeva preispitivanja prakse i promjene u poreznim zakonodavstvima pojedinih članica, i to na dva načina. Nacionalni sudovi mogu uputiti nacionalnu poreznu odredbu Sudu na ,preliminarni postupak“. Pokretanjem takvog postupka, države Europske unije od Suda zahtijevaju odgovor na pitanje o usklađenosti vlastitoga poreznog prava s pravom Europske unije. Predmet Sudu može uputiti i Europska komisija, kada smatra da neka članica

nad izvršenjem pravomoćnih presuda. Stranka nezadovoljna ishodom sudskog spora, može, u roku od 12 mjeseci, od vijeća zahtijevati tumačenje ili ispitivanje presude. Preispitivanje se može tražiti zbog naknadnog otkrivanja činjenica koje nisu bile poznate Sudu i stranci u vrijeme donošenja odluke, a mogle su bitno utjecati na sadržaj meritorne odluke. Pravomoćne i izvršne sudske odluke postaju izvor prava, odnosno osnova svih budućih odlučivanja. Navedeno prema: http://www.echr.coe.int/echr/, http://europa. eu/institutions/inst/justice/index_en.htm.

${ }_{33} \mathrm{http}: / /$ www.echr.coe.int/echr/, http://europa.scp.hr/europski_sud_pravde.htm, http://europa.eu/ institutions/inst/justice/index_en.htm. 
krši pravila Europske unije. Komisija će to učiniti samo ako neka država, na zahtjev ne uspije ispraviti vlastiti zakon. ${ }^{34}$

Europska komisija ima značajnu ulogu u primjeni propisa o oporezivanju dobiti. Zanimljivo je navesti nekoliko slučajeva na primjer odobravanje neopravdanih povlastica Irske prema Appleu, davanje selektivnih državnih potpora koje je Belgija dodijelila u okviru svojeg sustava oporezivanja „,viška dobiti“ i drugi.

U prvom slučaju dana 30. kolovoza 2016. godine Europska komisija zaključila je da je Irska Appleu odobravala neopravdane porezne povlastice u vrijednosti do 13 milijardi eura. To je protivno pravilima Europske unije o državnim potporama, jer je Appleu omogućilo plaćanje bitno manjeg poreza od drugih poduzeća. Irska sada mora osigurati povrat nezakonite pomoći. ${ }^{35}$

U Komisijinoj istrazi zaključeno je, kako je već rečeno, da je Irska Appleu odobravala nezakonite porezne povlastice, što mu je omogućilo da dugi niz godina plaća bitno manji porez nego druga poduzeća. Konkretno, tim je selektivnim ponašanjem Appleu omogućeno plaćanje poreza na dobit ostvarenu u Europi po efektivnoj stopi poreza na dobit od 1\% 2003. godine koja se 2014. godine smanjila na $0,005 \%$. Nakon dubinske istrage Europska komisija zaključila je da je dvama rješenjima, koje je izdala Irska, bitno i umjetno umanjen porez što ga je Apple u Irskoj plaćao od 1991. godine. Rješenjima je odobren način utvrđivanja oporezive dobiti u dvama irskim poduzećima grupe Apple (Apple Sales International i Apple Operations Europe $)^{36}$ koji nije odgovarao ekonomskoj stvarnosti: gotovo sva dobit od prodaje, evidentirana u tim dvama poduzećima, interno je pripisana ,sjedištu“. Komisijina procjena pokazala je da su ta ,sjedišta“ postojala samo na papiru i nisu mogla ostvariti takvu dobit. Ta dobit pripisana „sjedištima“ nije podlijegala plaćanju poreza ni u jednoj državi u skladu s posebnim odredbama irskog poreznog zakona koji više nisu na snazi.

To selektivno porezno postupanje Irske prema Appleu nezakonito je prema pravilima Europske unije o državnim potporama, jer Appleu daje znatnu prednost nad drugim poduzećima što podliježu istim nacionalnim poreznim pravilima. Komisija može naložiti povrat nezakonite državne potpore u desetogodišnjem

34 N. Mijatović, ,Oporezivanje u Europskoj uniji: promicanje unutarnjeg tržišta i ekonomskog rasta“, Porezni vjesnik, br. 4., Ministarstvo financija, Porezna uprava, Središnji ured, Zagreb, 2015., str. 123-124.

35 http:// europa . eu > press - release_ IP -16-2923_hr (PDF), www. theverge . com, www.bbc.co. uk $>$ business - 37220799 .

36 Apple Sales International i Apple Operations Europe dva su irska poduzeća u potpunom vlasništvu grupe Apple, pod krajnjom kontrolom matičnog poduzeća Apple Inc. iz Sjedinjenih Američkih Država. Nositelji su prava na korištenje Appleova intelektualnog vlasništva u cilju prodaje i proizvodnje Appleovih proizvoda izvan Sjeverne i Južne Amerike u okviru tzv. ,sporazuma o podjeli troškova“ s Apple Inc. Prema tom sporazumu, Apple Sales International i Apple Operations Europe jedanput na godinu Appleu u Sjedinjenim Američkim Državama doznačuju sredstva za financiranje istraživačkih i razvojnih aktivnosti koje se u Sjedinjenim Američkim Državama poduzimaju u korist tih dvaju irskih poduzeća. Iznos tih plaćanja 2011. godine dosegnuo je oko 2 milijarde američkih dolara, a 2014. godine znatno se povećao. Tim troškovima, koje je većinom snosio Apple Sales International, financirano je više od polovine svih istraživačkih aktivnosti grupe Apple u Sjedinjenim Američkim Državama u cilju razvoja njezina intelektualnog vlasništva u svijetu. U skladu s primjenjivim pravilima, ti se troškovi svake godine oduzimaju od dobiti koju su u Irskoj evidentirali Apple Sales International i Apple Operations Europe. 
razdoblju što je prethodilo prvom zahtjevu Komisije za informacije u 2013. godini. Irska sad od Applea mora vratiti porez koji u Irskoj nije plaćen za razdoblje od 2003. godine do 2014. godine u vrijednosti do 13 milijardi eura, uvećano za kamate.

Takav porezni tretman u Irskoj zapravo je Appleu omogućio izbjegavanje plaćanja poreza na gotovo svu dobit ostvarenu prodajom Appleovih proizvoda na cijelom jedinstvenom tržištu Europske unije. Razlog je tomu Appleova odluka da svu prodaju evidentira u Irskoj umjesto u državama u kojima su proizvodi bili prodani, no ta struktura nije u nadležnosti kontrole državnih potpora Europske unije. Ako druge države u skladu sa svojim nacionalnim poreznim pravilima zatraže od Applea da plati više poreza na dobit dvaju poduzeća ostvarenu u istom razdoblju, time bi se smanjila ukupna svota povrata koji mora osigurati Irska.

U drugom slučaju dana 11. siječnja 2016. godine Europska komisija zaključila je da su selektivne porezne povlastice, koje je Belgija dodijelila u okviru svojeg sustava oporezivanja «viška dobiti», prema pravilima Europske unije o državnim potporama nezakonite. Tim je sustavom najmanje 35 multinacionalnih poduzeća, uglavnom iz Europske unije, ostvarilo korist, te sada moraju Belgiji vratiti neplaćeni porez. ${ }^{37}$

Belgijskim sustavom oporezivanja „viška dobiti“, koji se primjenjuje od 2005. godine određenim poduzećima multinacionalnih grupa omogućeno je plaćanje znatno manjeg poreza u Belgiji na temelju poreznih mišljenja. Tim je sustavom osnovica poreza na dobit za poduzeća smanjena za $50 \%$ do $90 \%$ kako bi se od osnovice odbili takozvani «viškovi dobiti» koji su navodno posljedica pripadanja multinacionalnoj grupi. Komisijinom detaljnom istragom započetom u veljači 2015. godine pokazalo se da se tim sustavom odstupa od uobičajene prakse u okviru belgijskih poreznih pravila za poduzeća i takozvanog ,načela transakcije po tržišnim uvjetima“" (eng. the arm's length principle). To je prema pravilima Europske unije o državnim potporama nezakonito. ${ }^{38}$

Sustav oporezivanja «viška dobiti» porezne su vlasti promovirale pod sloganom „Samo u Belgiji“. Njime su korist ostvarile samo određene multinacionalne grupe koje su dobile porezno mišljenje na temelju tog sustava, dok samostalna poduzeća (tj. poduzeća koja nisu dio grupe) aktivna isključivo u Belgiji, nisu mogla ostvariti slične koristi. Tim se sustavom vrlo ozbiljno narušava tržišno natjecanje unutar jedinstvenog tržišta Europske unije, te utječe na širok spektar gospodarskih sektora.

\footnotetext{
37 http://europa.eu>press-release_IP-16-42_hr (PDF), https://www.stible.com $>$ news $>$ february, https://euobserver.com>economic.

38 Povjerenica za politiku tržišnog natjecanja Margrethe Vestager izjavila je: „Belgija je određenom broju multinacionalnih poduzeća dala znatne porezne povlastice kojima se krše pravila Europske unije o državnim potporama“. Time se narušava tržišno natjecanje na temelju zasluga tako što se manje konkurente, koji nisu multinacionalna poduzeća, stavlja u neravnopravan položaj. Mnogo je zakonitih načina na koje države članice Europske unije mogu subvencionirati ulaganja i mnogo je dobrih razloga za ulaganja u Europskoj uniji. Međutim, ako država članica nekim multinacionalnim poduzećima daje nezakonite porezne povlastice kojima im se omogućuje izbjegavanje plaćanja poreza na većinu njihove stvarne dobiti, time ona ozbiljno šteti poštenom tržišnom natjecanju u Europskoj uniji, što u konačnici šteti građanima Europske unije.
} 
Multinacionalna poduzeća koja su ostvarila korist od navedenog sustava uglavnom su europska poduzeća koja su u okviru tog sustava izbjegla plaćanje većine poreza, a sada ih moraju vratiti Belgiji.

Komisija procjenjuje da je riječ o ukupnom iznosu od približno 700 milijuna eura.

Belgijskim poreznim pravilima za poduzeća zahtijeva se da se poduzeća oporezuju na temelju dobiti stvarno zabilježene po osnovi djelatnosti obavljenih u Belgiji. Međutim, sustavom oporezivanja «viška dobiti» iz 2005. godine koji se temelji na čl. 185. st. 2. toč.(b) Zakona o porezu na dobit, ${ }^{39}$ multinacionalnim poduzećima omogućeno je da smanje poreznu osnovicu zbog navodnog «viška dobiti» na temelju obvezujućeg poreznog mišljenja. Ta su mišljenja obično bila važeća četiri godine i mogla su se obnoviti.

Prema tim poreznim mišljenjima stvarno zabilježena dobit multinacionalnog poduzeća uspoređuje se s hipotetskom prosječnom dobiti koju bi ostvarilo samostalno poduzeće u usporedivoj situaciji. Belgijska porezna tijela navodnu razliku u dobiti smatraju «viškom dobiti», te se porezna osnovica multinacionalnog poduzeća razmjerno smanjuje. To se temelji na pretpostavci da multinacionalna poduzeća ostvaruju «višak dobiti» zato jer pripadaju multinacionalnoj grupi, primjerice zbog sinergija, ekonomije razmjera, ugleda, mreža klijenata i dobavljača ili pristupa novim tržištima. U praksi je, kako je već navedeno, stvarno zabilježena dobit predmetnih poduzeća obično smanjivana za više od 50\%, a u nekim slučajevima i za $90 \%$.

Komisijinom detaljnom istragom pokazalo se da se tim sustavom, kojim se odbija «višak dobiti» od stvarne porezne osnovice poduzeća, odstupa od: a) uobičajene prakse u okviru belgijskih poreznih pravila za poduzeća ${ }^{40}$ i b) ,načela transakcije po tržišnim uvjetima“" (engl. the arm's length principle) prema pravilima Europske unije o državnim potporama. ${ }^{41}$

39 Code des Impôts sur les Revenus ili Wetboek Inkomstenbelastingen, poglavlje u knjizi: J. P. Bours, C. Devoet, Impôts sur les Revenus, Le régime fiscal des plans de pension complémentaire pour indépendants, Isabel Group, Bruxelles, 2008.

40 Njime se multinacionalnim poduzećima koja su mogla dobiti takvo porezno mišljenje daje povlaštena, selektivna potpora u odnosu na druga poduzeća. Točnije, najmanje 35 poduzeća dobilo je nepoštene konkurentske porezne povlastice u odnosu na, primjerice, svakog njihovog samostalnog konkurenta koji je dužan plaćati poreze na temelju svoje stvarne dobiti zabilježene u Belgiji prema uobičajenim belgijskim poreznim pravilima za poduzeća.

${ }_{41}$ Čak i ako se pretpostavi da multinacionalno poduzeće ostvari „,višak dobiti“, on bi se prema načelu transakcije po tržišnim uvjetima podijelio među poduzećima te grupe na način koji odražava gospodarsku stvarnost te bi se oporezivao tamo gdje bi nastao. Međutim, u okviru belgijskog sustava „viška dobiti“ ta se dobit jednostavno jednostrano odbija od porezne osnovice pojedinačne grupe poduzeća.

Selektivne porezne povlastice tog sustava ne mogu se opravdati ni argumentom koji je iznijela Belgija da su smanjenja nužna kako bi se izbjeglo dvostruko oporezivanje. U stvari, Belgija je jednostrano uvela te prilagodbe, tj. one nisu povezane sa zahtjevima iz drugih država članica za oporezivanje iste dobiti. Navedenim se sustavom od poduzeća ne zahtijeva da pruže dokaze o dvostrukom oporezivanju niti čak da pokažu rizik od dvostrukog oporezivanja. Zapravo, on je doveo do dvostrukog neoporezivanja. Stoga se tim sustavom poduzećima daje povlašteni porezni tretman koji je prema pravilima EU-a o državnim potporama nezakonit (čl. 107. Ugovora o funkcioniranju Europske unije). 
Otkako je Komisija pokrenula istragu u veljači 2015. godine Belgija je privremeno obustavila sustav „viška dobiti“ i nije izdala nijedno novo porezno mišljenje u okviru tog sustava. Međutim, poduzeća koja su već primila porezna mišljenja u okviru tog sustava od početka njegove primjene 2005. godine i dalje su ostvarivala korist zahvaljujući tom sustavu.

Odlukom Komisije od Belgije se zahtijeva da i u budućnosti prestane primjenjivati sustav „viška dobiti“. Osim toga, kako bi se uklonila nepoštena prednost koju su ostvarili korisnici tog sustava, i kako bi se ponovno uspostavilo pravedno tržišno natjecanje, Belgija sada mora osigurati povrat punog iznosa neplaćenog poreza od najmanje 35 multinacionalnih poduzeća, koja su ostvarila korist od tog nezakonitog sustava. Belgijska porezna tijela sada moraju utvrditi koja su poduzeća zaista nezakonitim sustavom oporezivanja ostvarila korist, te koji su točni iznosi poreza koje svako poduzeće mora vratiti. Komisija, kako je već navedeno, procjenjuje da se radi o ukupnom iznosu od približno 700 milijuna eura.

\section{PREMA PRAVEDNIJEM I UČINKOVITIJEM SUSTAVU OPOREZIVANJA DOBITI TRGOVAČKIH DRUŠTAVA U EUROPSKOJ UNIJI}

Dana 17. lipnja 2015. godine Komisija je predstavila Akcijski plan za reformu temelja oporezivanja trgovačkih društava u Europskoj uniji. Akcijski plan navodi niz inicijativa za rješavanje problema izbjegavanja plaćanja poreza i kako osigurati održive prihode i ojačati jedinstveno tržište za trgovačka društva u okviru Europske unije. Ove mjere će značajno poboljšati okruženje oporezivanja trgovačkih društava u Europskoj uniji, i učiniti ga pravednijim i učinkovitijim. ${ }^{42}$

Akcijski plan je temelj za uspostavu pravednijeg i za rast poticajnog sustava oporezivanja dobiti trgovačkih društava u Europskoj uniji. Predložene mjere doprinijet će postizanju stabilnosti prihoda, jačeg jedinstvenog tržišta, veće otpornosti i efikasnosti poduzeća, te pravednog poslovnog okruženja u kojem vrijede jednaka pravila za sve.

U Akcijskom planu određena su ključna područja na kojima je potrebno raditi kratkoročno, srednjoročno i dugoročno. Usklađivanje stopa poreza na dobit nije dio tog plana. Cilj je koordinirati porezne sustave država članica kako bi se one mogle učinkovitije boriti protiv agresivnog poreznog planiranja.

Prema navedenim ciljevima, Europska komisija navodi pet područja djelovanja, u kojima su akcije s razine Europske unije najučinkovitiji način sučeljavanja s izazovima u području oporezivanja dobiti poduzeća i određenim oblicima zlouporabe. Unutar svakog područja prepoznaju se mjere pogodne za provedbu željenih ciljeva.

42 European Commission (2015), Communication from the Commission to the European Parliament and the Council: A Fair and Efficient Corporate Tax System in the European Union: 5 Key Areas for Action. $\operatorname{COM}(2015) 302$ final. 
Područja djelovanja su sljedeća:

1) Holističko rješenje problema premještanja dobiti obuhvaća - Zajedničku konsolidiranu osnovicu poreza na dobit (engl. Common Consolidated Corporate Tax Base - CCCTB) ${ }^{43}$ koju je Komisija predložila u 2011. godini, a mogla bi biti iznimno učinkovito sredstvo za ispunjavanje ciljeva pravednijeg i učinkovitijeg oporezivanja. Uvođenjem CCCTB-a uvelike bi se poboljšalo okruženje za poduzeća u Europskoj uniji. To je jedna od inicijativa Komisije u okviru programa REFIT (program Europske komisije kojim se želi osigurati prikladnost i učinkovitost propisa), a cilj je smanjivanje administrativnog opterećenja i pojednostavljivanje jedinstvenog tržišta za poduzeća. Primjena CCCTB-a dovela bi do pojednostavnjenja i smanjenja troškova usklađivanja za prekogranična poduzeća, koja bi pri izračunu oporezive dobiti morala slijediti samo jedan skup pravila umjesto 28 različitih sustava. Osim toga, konsolidacija grupama nudi značajnu prednost time što gubitke nastale u jednoj državi članici mogu kompenzirati s dobiti ostvarenom u drugoj. ${ }^{44}$

2) Osiguravanje efektivnog oporezivanja na mjestu ostvarenja dobiti - poduzeća koja imaju koristi od jedinstvenog tržišta i na njemu ostvaruju dobit, morala bi plaćati porez na tu dobit unutar Europske unije, na mjestu obavljanja gospodarske aktivnosti. Međutim, neka poduzeća iskorištavaju neusklađenosti u nacionalnim poreznim propisima kako bi premještala dobit. Premještaju dobit s mjesta, na kojem je ostvarena, u države članice s niskim poreznim stopama i povlaštenim režimima te u treće zemlje koje nemaju nikakve veze s mjestom na kojem je stvorena vrijednost. Na temelju postojećeg zakonodavstva o oporezivanju dobiti poduzeća, oporezivanje u jednoj državi članici može se onemogućiti premještanjem dobiti u drugu državu članicu. Kao rezultat toga postoje dokazi da neka multinacionalna poduzeća plaćaju iznimno niske efektivne poreze (ili ih uopće ne plaćaju) na mjestu stvarnog obavljanja gospodarske aktivnosti, čak ako ondje i ostvaruju znatnu dobit. Osiguravanje efektivnog oporezivanja na mjestu ostvarenja dobiti odnosi se na:

a) približavanje oporezivanja mjestu ostvarenja dobiti i osiguravanje efektivnog oporezivanja dobiti - krajnji učinak ove mjere trebao bi biti zaštita prava država članica na porezne prihode nastale na jedinstvenom tržištu i smanjenje mogućnosti određenih poduzeća da u potpunosti izbjegnu oporezivanje;

b) poboljšanje sustava transfernih cijena u Europskoj uniji - cilj je pravila o transfernim cijenama osigurati da je cijena transakcije unutar grupe jednaka usporedivoj tržišnoj cijeni i da se dobit pravedno dijeli među jurisdikcijama $\mathrm{u}$ kojima multinacionalno poduzeće posluje. Međutim, jasno je da u modernom gospodarstvu postojeći sustav transfernih cijena više nije učinkovit. I poduzeća i porezne uprave smatraju da je postojeći sustav složen. Nadalje, poduzeća mogu

43 O zajedničkoj konsolidiranoj osnovici poreza na dobit bit će više riječi poslije.

44 Podrobnije vidjeti u: N. Mijatović, „Zajednička konsolidirana osnovica poreza na dobitak aktualno stanje i prijedlozi EU“, Pravo i porezi, br. 7.-8., RRIF, Zagreb, 2012., str. 85-94. 
manipulirati sustavom kako bi premjestila dobit u jurisdikcije s niskom stopom poreza ili bez poreza; ${ }^{45}$

c) povezivanje povlaštenih režima s mjestom stvaranja vrijednosti - čini se da se određeni povlašteni porezni režimi, umjesto za istinsko poticanje gospodarskih aktivnosti za koje postoje porezne olakšice, iskorištavaju za izbjegavanje plaćanja poreza. Na primjer, poduzeće može smjestiti svoje intelektualno vlasništvo u zemlji različitoj od one u kojoj stvarno obavlja svoje aktivnosti istraživanja i razvoja kako bi iskoristilo povlašteni porezni tretman, a posebno povlaštene porezne režime za patente. Radi rješavanja tog problema, Skupina za Kodeks o postupanju pri oporezivanju poslovanja je u 2014. godini odlučila da bi se povlašteni porezni režimi, npr. u slučaju patenata, morali temeljiti na ,izmijenjenom pristupu nexus“. ${ }^{46}$ To znači da porezne olakšice moraju biti izravno povezane s relevantnim aktivnostima istraživanja i razvoja.

3) Dodatne mjere za poboljšanje poreznog okruženja za poduzeća - bilo kakvo preispitivanje sustava oporezivanja dobiti poduzeća u Europskoj uniji mora biti čvrsto usredotočeno na stvaranje okruženja koje potiče poduzetništvo te rast $\mathrm{i}$ zapošljavanje na jedinstvenom tržištu. Kako je prethodno navedeno, nekontrolirana porezna konkurencija, kojom se olakšava agresivno porezno planiranje nekih poduzeća, narušava tržišno natjecanje poduzeća, otežava oporezivanje koje bi trebalo podržavati rast i fragmentira jedinstveno tržište. Dodatne mjere za poboljšanje poreznog okruženja za poduzeća obuhvaćaju:

a) omogućavanje kompenzacije prekograničnih gubitaka drugim riječima Komisija će predložiti da se, dok ne dođe do potpune konsolidacije CCCTB-a, grupama omogući kompenzacija dobiti i gubitaka nastalih u različitim državama članicama. Time bi se otklonila velika porezna prepreka za poduzeća na jedinstvenom tržištu, omogućujući im privremene naknade prekograničnih gubitaka time što bi porez plaćala na svoju neto dobit u Europskoj uniji;

b) poboljšanje mehanizama rješavanja sporova u području dvostrukog oporezivanja znači da do dvostrukog oporezivanja dolazi kada različite države članice oporezuju istu dobit. To može biti velika porezna prepreka za poduzeća koja posluju u više od jedne države članice, koja im stvara nepotrebne troškove i administrativno opterećenje. Dvostruko oporezivanje na jedinstvenom tržištu ima negativan utjecaj na prekogranična ulaganja i dovodi do gospodarskih poremećaja i neučinkovitosti. Zajedničkom poreznom osnovicom iz prijedloga o CCCTB-u uklonio bi se rizik od dvostrukog oporezivanja u Europskoj uniji. Međutim, dok se ne postigne dogovor o tome, potrebna su alternativna rješenja.

Države članice većinom su međusobno potpisale bilateralne porezne ugovore kako bi ublažile problem eventualnog dvostrukog oporezivanja, a uspostavljeni su

45 I. Verlinden, P. Deré, ,The European Commission Action Plan for a Fair and Efficient Tax System in the European Union: What Should Be Expected?", No. 22., 6., International Transfer Pricing Journal, 2015. pdf.

46 http://www.oecd.org/ctp/beps-action-5-agreement-on-modified-nexus-approach-for-ip-regimes. 
i postupci rješavanja mogućih sporova. Međutim, ti su postupci dugotrajni, skupi i ne riješe se uvijek dogovorom. ${ }^{47}$

U tom je smislu korisna multilateralna arbitražna konvencija država članica o rješavanju sporova. Područje primjene arbitražne konvencije ograničeno je na sporove o transfernim cijenama i njome nije predviđeno podnošenje žalbe zbog tumačenja pravila.

4) Daljnji koraci prema većoj poreznoj transparentnosti - transparentnost je ključni element u osiguravanju pravednijeg oporezivanja, kako u Europskoj uniji tako i na međunarodnoj razini. Ona je važna za suzbijanje zlouporabe poreznog sustava i povezivanje oporezivanja s mjestom obavljanja gospodarske aktivnosti. Transparentnost obuhvaća:

a) U 2012. godini Komisija je izdala preporuke o mjerama za suzbijanje agresivnog poreznog planiranja i poticanje trećih zemalja na primjenu minimalnih standarda dobrog upravljanja u poreznim pitanjima, te se obvezala sastaviti izvješće o njihovoj primjeni u roku od tri godine. Cilj je bio uspostaviti zajednički pristup identifikaciji nekooperativnih poreznih jurisdikcija i postupanju prema njima, čime bi Europska unija zauzela čvršći stav u odnosu na te jurisdikcije.

Kao prvi korak Komisija je, na temelju neovisnih nacionalnih „crnih lista“ država članica, objavila popis nekooperativnih poreznih jurisdikcija trećih zemalja koji vrijedi za cijelu Europsku uniju, a o kojima se raspravljalo u okviru platforme za dobro porezno upravljanje u prosincu 2014. godine.

Na popis koji objedinjuje sve države članice Europske unije uključene su jurisdikcije koje je identificiralo najmanje 10 država članica. Popis je objavljen na web-mjestu Komisije, ${ }^{48}$ a države članice se tim transparentnim alatom koriste za međusobnu usporedbu svojih nacionalnih popisa i, prema potrebi, za usklađivanje svojih pristupa nekooperativnim poreznim jurisdikcijama. Komisija će u budućnosti redovito ažurirati taj popis ovisno o tome kako će države članice mijenjati svoje popise.

b) Daljnji rad na transparentnosti oporezivanja dobiti poduzeća, poput opcija izvješćivanja po zemljama - kao što je najavljeno u paketu mjera za poreznu transparentnost iz ožujka 2015. godine, Komisija procjenjuje postoji li potreba za uvođenjem dodatnih obveza objavljivanja određenih informacija o oporezivanju dobiti poduzeća. ${ }^{49}$

5) Koordinacijski instrumenti Europske unije - suradnja među državama članicama ključni je element u borbi protiv izbjegavanja plaćanja poreza i agresivnog poreznog planiranja. Zakonodavstvom Europske unije predviđena je administrativna suradnja među poreznim tijelima država članica i niz instrumenata s pomoću kojih će lakše surađivati u prikupljanju svojih poreznih prihoda. Komisija

47 http://ec.europa.eu/taxation_customs/common/consultations/tax/2010_04_doubletax_en.htm.

48 eu/taxation_customs/taxation/gen_info/good_governance_matters/lists_of_countries/index_ en.htm.

$49 \mathrm{https} / /$ ec.europa.eu/eusurvey/further-corporate-tax-transparency-2015/management/test. 
smatra da je efektivna primjena tih instrumenata trenutačno suboptimalna i da bi države članice mogle imati koristi od njihova boljeg iskorištavanja. Koordinacijski instrumenti Europske unije obuhvaćaju:

a) Bolja koordinacija država članica u području porezne revizije - Smjernicom o administrativnoj suradnji predviđena je suradnja među državama članicama u područjima porezne inspekcije i revizije, te se njome potiče razmjena najboljih praksi među poreznim tijelima. Međutim, ti se instrumenti još ne primjenjuju u potpunosti, a raznoliki nacionalni pristupi reviziji korporacija u velikom su nerazmjeru s visoko-sofisticiranim tehnikama poreznog planiranja nekih poduzeća. Komisija će stoga poticati veću suradnju između država članica u tom području. U okviru Platforme za dobro porezno upravljanje pokrenut će raspravu s državama članicama kako bi se pronašao način za daljnji razvoj strateškog pristupa kontroli i reviziji prekograničnih poduzeća.,

b) Reforma Kodeksa o postupanju pri oporezivanju poslovanja i Platforme za dobro porezno upravljanje - Skupina za Kodeks o postupanju pri oporezivanju poslovanja, sastavljena od predstavnika država članica, bavi se rješavanjem problema štetne porezne konkurencije u Europskoj uniji na neobvezujući način, temeljem uzajamnog pritiska. Brojne države članice i dionici podržali su ideju o produljenju mandata Kodeksa i promjeni radnih metoda Skupine, kako bi mogla učinkovitije reagirati na slučajeve štetne porezne konkurencije. Skupina bi isto tako trebala davati smjernice za provedbu nezakonodavnih mjera Europske unije protiv izbjegavanja plaćanja poreza na dobit. Komisija će predložiti da se Kodeks o postupanju pri oporezivanju poslovanja izmijeni u skladu s tim reformama i u bliskoj suradnji s državama članicama. ${ }^{50}$

\section{PRIJEDLOG SMJERNICE VIJEĆA EUROPSKE KOMISIJE O ZAJEDNIČKOJ OSNOVICI POREZA NA DOBIT (CCCTB) COM (2016)}

Raspravama u Vijeću od 2011. godine do danas pokazalo se da donošenje ambicioznog prijedloga poput prijedloga o CCCTB-u nije vjerojatno provesti u cijelosti i bez postupnog pristupa. Stoga su različiti elementi (posebno porezna konsolidacija) izazvali ozbiljnu raspravu i mogli bi usporiti napredak u pogledu ostalih temeljnih značajki sustava. Komisija je u svom akcijskom planu od lipnja 2015. godine zagovarala pristup CCCTB-u korak po korak, kako bi riješila problem usporavanja napretka. U skladu s time predloženo je da se rad na konsolidaciji odgodi do postizanja dogovora o obveznom skupu pravila za zajedničku osnovicu, to jest zajedničku osnovicu poreza na dobit. Neovisno o tome Komisija će istodobno podnijeti dva prijedloga, to jest za zajedničku osnovicu poreza na dobit i za CCCTB,

50 Podrobnije vidjeti u: S. Gadžo, Oporezivanje dobiti u Europskoj uniji... o. c., str. 104.-106., N. Mijatović, Akcijski plan Europske unije za temeljitu reformu oporezivanja trgovačkih društava, Novi informator, br. 6373., Zagreb, 2015. 
kao dio jedinstvene inicijative. Prijedlog iz 2011. godine o CCCTB-u, koji je još uvijek u postupku u Vijeću, povući će se čim Komisija donese nove prijedloge. U tom je pogledu ključno da porezna konsolidacija ostane temeljni element inicijative CCCTB-a, jer je glavne porezne prepreke s kojima se suočavaju trgovačka društva u Uniji, moguće najdjelotvornije ukloniti unutar konsolidirane grupe.

Inicijativa CCCTB-a ponovno je pokrenuta zbog olakšavanja poslovanja unutar Europske unije podvrgavanjem poreznih obveznika jedinstvenom pravilniku u pogledu zakonodavstva o oporezivanju dobiti poduzeća, koji će se primjenjivati diljem unutarnjeg tržišta te zbog osiguranja izdržljivosti i otpornosti sustava na agresivno porezno planiranje. Oba cilja imaju odlučujuć i izravan utjecaj na unutarnje tržište upravo zato jer im je svrha iskorjenjivanje poremećaja u njegovu funkcioniranju.

Stoga je Europske komisija 25. listopada 2016. godine donijela prijedlog Smjernica o zajedničkoj osnovici poreza na dobit (CCCTB). ${ }^{51}$ Ovaj prijedlog je obuhvaćen područjem primjene članka 115. Ugovora o funkcioniranju Europske unije. Tekstom se propisuje da mjere za usklađivanje u okviru toga članka neposredno utječu na uspostavu i funkcioniranje unutarnjeg tržišta. ${ }^{52}$

Glavna razmatrana mogućnost politike jest prijedlog zajedničke konsolidirane osnovice poreza na dobit, no također su ocijenjene posljedice prve faze bez konsolidacije. Potrebno je donijeti ključnu odluku u vezi s područjem primjene takve porezne osnovice, to jest o tome na koga bi se ona primjenjivala. Mogućnosti da CCCTB postane obvezan za sva poduzeća ili samo za podskupinu poduzeća uzete su u obzir kao temeljne. Razmotrene su razne mogućnosti kako bi se riješio problem povlaštenog poreznog tretmana duga koji uzrokuju važeći porezni sustavi. Moguće je poduzeti dvije glavne mjere: omogućiti istodobno odbijanje troškova financiranja u pogledu duga i vlasničkog kapitala ili ga uskratiti za obje opcije. U pogledu poticaja za istraživanje i razvoj, glavnim se mogućnostima predviđa porezna olakšica za troškove ulaganja u istraživanje i razvoj s različitim stupnjevima povoljnosti. Vrednovanje različitih mogućnosti dovelo je do mogućnosti kojoj je dana prednost: CCCTB koji bi bio obvezan za velika trgovačka društva te sadržavao olakšicu za rast i ulaganje i olakšicu za troškove istraživanja i razvoja. Olakšicom za rast i ulaganje dodjeljuju se odbici za troškove financiranja u pogledu duga i vlasničkog kapitala unutar ograničenja zbog izbjegavanja zlouporaba i poreznog

51 Proposal for a Council Directive on a Common Corporate Tax Base, Strasbourg, European Commision, COM (2016.) 685 FINAL.

${ }^{52}$ Komisija je organizirala javno savjetovanje radi uključivanja svih dionika i pružanja mogućnosti zainteresiranim stranama da izraze svoje mišljenje o ponovnom pokretanju CCCTB-a. U postupku savjetovanja sudjelovalo je 175 sudionika. Najviše odgovora pružila su registrirana udruženja (37\%) i pojedina trgovačka društva (32\%), većinu kojih čine mala i srednja poduzeća (MSP-ovi) čime se ističe interes manjih trgovačkih društava za ovaj prijedlog. Ovisno o vrsti ispitanika, postoje razlike u stajalištima o tome je li CCCTB prikladan instrument za rješavanje problema premještanja dobiti i smanjenje administrativnog opterećenja. Iako je ukupni dojam prijedloga pozitivan, javna tijela posebno su istaknula učinak CCCTB-a na aktivnosti poreznog planiranja. Poduzeća su u većoj mjeri naglasila važnost smanjenja troškova usklađivanja i stvaranja poduzetništvu naklonjenog okruženja za ulaganja. Ipak, također su naglasila rizike od nastanka viših administrativnih troškova ako će se sustav većinom temeljiti na pravilima protiv izbjegavanja poreza. 
planiranja. Olakšica za troškove istraživanja i razvoja osmišljena je kako bi barem održala postojeće porezne poticaje za istraživanje i razvoj. Analiza pokazuje da CCCTB ima jasne prednosti u odnosu na alternativu, odnosno izostanak djelovanja.

Očekuje se da će se provedbom izbora, kojemu je dana prednost, povećati pravednost poreznih sustava i stvoriti jednaki uvjeti za sve kao rezultat učinkovitog uklanjanja poticaja za agresivno porezno planiranje u Europskoj uniji. Time bi se osiguralo da društva snose pravedan dio poreznog opterećenja i povećao moral poreznih obveznika. Nadalje, u praksi bi došlo do uklanjanja prekograničnih poreznih prepreka unutar Europske unije. Iako je očito da je konsolidacija važan element za smanjenje izbjegavanja poreza, pravilima za zajedničku osnovicu bi se već stalo na kraj nekim oblicima premještanja dobiti, kao što je iskorištavanje neusklađenosti u međudjelovanju poreznih sustava. Poremećaji u vezi s odlukama trgovačkih društava o financiranju smanjit će se s pomoću olakšice za rast i ulaganje, kojom će se financiranje vlasničkim kapitalom i financiranje dugom staviti u sličan položaj. Porezni poticaji za istraživanje i razvoj nisu samo zadržani, već su unaprijeđeni i pojednostavnjeni.

Očekuju se pozitivne ekonomske koristi prijedloga. Zajednička osnovica poreza na dobit s olakšicom za prekogranične gubitke te olakšicom za rast i ulaganje dovela bi do povećanja razine ulaganja i zaposlenosti do 3,6 \% odnosno 0,5 \%. Sveukupno bi se rast povećao do $1,3 \%$. Očekuje se da će se troškovi usklađivanja smanjiti, pogotovo u okviru CCCTB-a (10 \% u pogledu vremena usklađivanja i 2,5\% u pogledu troškova usklađivanja). Trošak osnivanja društva kćeri smanjio bi se za $67 \%$, čime bi se trgovačkim društvima (uključujući MSP-ove) olakšalo širenje u inozemstvo.

Ne očekuje se da će mogućnost kojoj je dana prednost imati relevantne učinke na okoliš. Društveni će učinci također biti ograničeni.

Drugim riječima ponovno pokretanje CCCTB-a predviđeno je zbog pružanja odgovora na potrebu povećanja rasta i stvaranja radnih mjesta na unutarnjem tržištu, kao i zbog suzbijanja praksi agresivnog poreznog planiranja. Svi su ti ciljevi prije svega usmjereni na rješavanje problema izvan okvira pojedine države članice, te je stoga po prirodi potreban zajednički pristup. U tom svjetlu, bilo koje mjere mogle bi postići rezultate ako bi se pravila primjenjivala na ujednačen način diljem unutarnjeg tržišta. Kada to ne bi bio slučaj, situacija u području oporezivanja dobiti poduzeća ostala bi fragmentirana, čime bi se omogućio razvoj fiskalnih prepreka i praksi nepoštenog natjecanja u području oporezivanja. ${ }^{53}$

Većina ključnih obilježja sustava CCCTB-a mogla bi se ostvariti isključivo zajedničkim djelovanjem. Na primjer, neusklađenosti u pravnoj kvalifikaciji subjekata ili plaćanja, koje dovode do dvostrukog oporezivanja ili neoporezivanja, iskorijenile bi se primjenom zajedničkih pravila o oporezivanju dobiti trgovačkih društava. Odvojenim djelovanjem država članica ti bi se problemi u najboljem slučaju riješili na bilateralnoj razini. Olakšica za prekogranične gubitke prema definiciji bi

53 Proposal for a Council Directive on a Common Corporate Tax Base, Strasbourg, European Commision, COM (2016.) 685 FINAL., str. 1-7. 
bila najdjelotvornija ako bi je pružale sve države članice, iako ne treba isključiti bilateralni pristup kao drugo najbolje rješenje. Nadalje, restrukturiranje unutar grupe bez plaćanja poreza, uklanjanje složenih transfernih cijena unutar grupe i raspodjela prihoda na temelju formule na razini grupe, imaju temeljnu prekograničnu dimenziju te ih se može riješiti samo u kontekstu zajedničke regulacije. ${ }^{54}$

\section{1. Prikaz nekih odredbi Smjernice Vijeća Europske komisije o zajedničkoj osnovici poreza na dobit (CCCTB)}

Smjernica Vijeća Europske komisije o zajedničkoj osnovici poreza na dobit (CCCTB) sastoji se od XII. poglavlja. U nastavku ovog rada bit će prikazana prva dva poglavlja Smjernice.

U I. poglavlju Smjernice reguliran je predmet, područje primjene i definicije koje se odnose na sustav zajedničke osnovice za oporezivanje određenih trgovačkih društava, te se utvrđuju pravila za izračun te osnovice. Drugim riječima trgovačko društvo, koje primjenjuje pravila ove Smjernice, prestaje biti podložno nacionalnom pravu o porezu na dobit u pogledu svih pitanja, koja su regulirana ovom Smjernicom, osim ako nije drukčije navedeno (čl. 1.).

54 Sa stajališta porezne politike, CCCTB-om će se znatno poboljšati funkcioniranje jedinstvenog tržišta. Trgovačkim društvima koja posluju preko granica pri izračunu oporezive dobiti u Europskoj uniji pogodovat će jedinstven skup pravila umjesto šarolikosti različitih nacionalnih sustava. Preko sustava ,jedinstvene kontaktne točke“, društva će moći podnositi jednu poreznu prijavu za sve poslovne aktivnosti u Europskoj uniji te će tako kontaktirati samo s jednom državom članicom umjesto s više poreznih tijela. Konsolidacija će značiti i da se gubici u jednoj državi članici automatski mogu otpisati od dobiti u drugoj, čime se omogućuje jednako postupanje s trgovačkim društvima koja posluju preko granica kao s isključivo domaćim društvima.

U predloženoj Smjernici za ponovno uvođenje CCCTB-a Komisija je zadržala isti ambiciozan pristup konsolidaciji kakav je zauzela u izvornom prijedlogu. Međutim, pristupom koji obuhvaća dvije faze ta će se prednost odgoditi. Kako bi to nadoknadila, Komisija je predložila da trgovačka društva, dok se god ne postigne dogovor o konsolidaciji, trebaju imati pristup jednostavnom, stabilnom i privremenom sustavu prebijanja gubitaka u prekograničnom poslovanju unutar zajedničke osnovice.

CCCTB će biti jasan, stabilan i vezan za pravo Europske unije. O njemu će se jednoglasno dogovoriti sve države članice, čime će se jamčiti stabilan sustav koji neće biti usmjeren na redovite promjene. To će poduzećima omogućiti dosad najvišu razinu porezne sigurnosti. Društva se pri širenju preko granica više neće morati prilagođavati različitim poreznim propisima svake države članice. Više neće imati poteškoća u shvaćanju različitih pristupa država članica u oporezivanju određene dobiti niti će imati velike administrativne i pravne troškove kako bi svladala složenosti transfernih cijena. CCCTB-om uklonit će se glavne porezne prepreke s kojima se danas suočavaju poduzeća na jedinstvenom tržištu.

CCCTB-om se omogućuju velike pogodnosti (MSP-ovima) te velikim trgovačkim društvima u Europskoj uniji. CCCTB će biti obvezan samo za najveća trgovačka društva. Međutim, MSP-ovi i novoosnovana inovativna društva mogu se uključiti u ovaj sustav ako žele iskoristiti pojednostavnjenja i ostvariti uštede troškova koje on omogućuje. Trenutačno se procjenjuje da približno $30 \%$ poreza koji plaćaju MSP-ovi otpada na troškove ispunjavanja porezne obveze. Taj je postotak i viši ako se šire preko granica. CCCTB-om će se ti troškovi znatno smanjiti, kao i troškovi osnivanja podružnice u drugoj državi članici. Tim će se uštedama, uz pojednostavnjena pravila i jednostavniji sustav podnošenja porezne prijave, malim i novoosnovanim trgovačkim društvima znatno olakšati rast i širenje na jedinstvenom tržištu. Navedeno prema: Komunikacija Komisije Europskom parlamentu i Vijeću, Izgradnja pravednijeg i konkurentnijeg i stabilnijeg sustava oporezivanja dobiti poduzeća u Europskoj uniji, Strasbourg, 25. listopada 2016., Europska komisija COM (2016.) 682 FINAL. 
Prema čl. 2. pravila ove Smjernice primjenjuju se na trgovačko društvo koje je osnovano u skladu sa zakonima države članice, uključujući njegove stalne poslovne jedinice u drugim državama članicama, ako trgovačko društvo ispunjava sve sljedeće uvjete:

(a) ustrojeno je prema jednom od oblika poduzeća navedenih u Prilogu I.,

(b) podliježe jednom od navedenih poreza na dobit iz Priloga II. ili sličnom porezu koji je naknadno uveden,

(c) pripada, za potrebe financijskog računovodstva, konsolidiranoj grupi s ukupnim konsolidiranim prihodom grupe koji prelazi 750.000.000 EUR tijekom financijske godine koja prethodi relevantnoj financijskoj godini,

(d) smatra se matičnim trgovačkim društvom ili društvom kćeri koje ispunjava uvjete kako je navedeno u čl. 3. i/ili ima jedno ili više stalnih poslovnih jedinica u drugim državama članicama kako je navedeno u čl. 5.

Ova se Smjernica također primjenjuje na trgovačko društvo osnovano u skladu sa zakonima treće zemlje u pogledu njegovih stalnih poslovnih jedinica, koje se nalaze u jednoj ili više država članica, ako trgovačko društvo ispunjava uvjete utvrđene u st. 1. toč. od (b) do (d).

Trgovačko društvo koje ispunjava uvjete iz st. 1. toč. (a) i (b), ali ne ispunjava one iz toč. (c) i (d) tog stavka, može donijeti odluku o primjeni pravila ove Smjernice u razdoblju od pet poreznih godina, uključujući za svoje stalne poslovne jedinice koje se nalaze u ostalim državama članicama. To se razdoblje automatski produljuje za uzastopna razdoblja od pet poreznih godina, osim ako ne postoji obavijest o prestanku postojanja, kako je navedeno u čl. 65. st. 3. Uvjeti iz st. 1. toč. (a) i (b) ispunjavaju se svaki put kada dođe do produljenja razdoblja. ${ }^{55}$

Čl. 3. reguliran je odnos između matičnog društva i društva kćeri na način da društvo kći, koje ispunjava uvjete znači svako izravno društvo kći ili društvo kći nižeg ranga, u kojem matično trgovačko društvo ima sljedeća prava: a) pravo iskorištavanja više od $50 \%$ glasačkih prava, i b) pravo vlasništva nad kapitalom društva kćeri u udjelu većem od $75 \%$ ili posjeduje pravo na udio u dobiti veći od $75 \% .56$

Čl. 5. reguliran je pojam stalne poslovne jednice. Smatra se da porezni obveznik ima stalnu poslovnu jedinicu u državi članici, koja nije država članica u kojoj je rezident u svrhu oporezivanja, ako u toj drugoj državi članici ima stalno mjesto poslovanja preko kojega se u cijelosti ili djelomično odvija poslovanje poduzeća,

55 Pravila ove Smjernice ne primjenjuju se na brodarska društva podložna posebnom poreznom režimu. Brodarsko društvo podložno posebnom poreznom režimu uzima se u obzir za potrebe određivanja trgovačkih društava koja su članovi iste grupe kako je navedeno u čl. 3.

56 Za potrebe izračuna pragova u pogledu društva kćeri nižeg ranga primjenjuju se sljedeća pravila: a) kada se dosegne prag glasačkih prava u pogledu društva kćeri, smatra se da matično trgovačko društvo posjeduje $100 \%$ tih prava, b) pravo na dobit i vlasništvo kapitala izračunavaju se množenjem izravnih i neizravnih udjela u društvima kćerima na svakome rangu. Prava vlasništva u iznosu od $75 \%$ ili manje koje izravno ili neizravno posjeduje matično društvo, uključujući prava u trgovačkim društvima koja su rezidenti treće zemlje, također se uzimaju u obzir prilikom izračuna. 
uključujući posebno: sjedište uprave, podružnicu, ured, tvornicu, radionicu, rudnik, naftnu ili plinsku bušotinu, kamenolom ili bilo koje drugo mjesto na kojemu se vade prirodni resursi. Gradilište ili građevinski ili montažni projekt smatra se stalnom poslovnom jedinicom samo, ako traje dulje od 12 mjeseci.

U II. poglavlju Smjernice reguliran je izračun porezne osnovice. Člankom 7. regulirano je da se porezna osnovica izračunava umanjivanjem prihoda za neoporezive prihode, te umanjivanjem za troškove i ostale stavke koji se mogu odbiti.

Članak 8. regulira izuzete prihode, odnosno sljedeći prihodi nisu uključeni u poreznu osnovicu: a) potpore izravno povezane sa stjecanjem, izgradnjom ili poboljšanjem dugotrajne imovine koja podliježe amortizaciji, b) primici od prodaje skupa imovine kako je navedeno u čl. 37. st. 2., uključujući tržišnu vrijednost nenovčanih poklona, c) primici od prodaje dionica, pod uvjetom da je porezni obveznik održavao najmanje $10 \%$ udjela u kapitalu ili glasačkim pravima trgovačkog društva tijekom 12 mjeseci prije prodaje, uz iznimku primitaka nastalih prodajom dionica namijenjenih trgovanju, kako je navedeno u čl. 21. st. 3. i dionica u vlasništvu društava za životno osiguranje u skladu sa čl. 28. toč. b, primljene raspodjele dobiti, pod uvjetom da je porezni obveznik održavao najmanje $10 \%$ udjela u kapitalu ili glasačkim pravima trgovačkog društva tijekom 12 mjeseci uzastopno, uz iznimku raspodjela dobiti od dionica namijenjenih trgovanju, kako je navedeno u čl. 21. st. 4., i raspodjela dobiti koje su primila društva za životno osiguranje u skladu sa čl. 28. toč. c, prihod stalne poslovne jedinice koji je primio porezni obveznik u državi članici u kojoj je rezident u svrhu oporezivanja.

Čl. 9. regulira troškove koji se mogu odbiti samo u mjeri u kojoj su nastali u izravnom poslovnom interesu poreznog obveznika. Troškovi uključuju sve troškove prodaje i sve troškove bez odbijenog poreza na dodanu vrijednost, koje je porezni obveznik zabilježio u cilju ostvarenja ili osiguranja prihoda, uključujući troškove za istraživanje i razvoj, te troškove nastale pri prikupljanju kapitala ili duga u svrhu poslovanja. Zajedno s iznosima koji se mogu odbiti kao troškovi za istraživanje i razvoj, porezni obveznik također može u jednoj poreznoj godini odbiti dodatnih $50 \%$ od takvih troškova nastalih tijekom te godine, osim troškova povezanih s pokretnom materijalnom imovinom. U mjeri u kojoj troškovi za istraživanje i razvoj prelaze 20.000.000 eura, porezni obveznik može odbiti $25 \%$ od prijeđenog iznosa.

Porezni obveznik može odbiti dodatnih $100 \%$ svojih troškova za istraživanje i razvoj do 20.000.000 eura, ako ispunjava sljedeće uvjete: a) poduzeće nije uvršteno na burzi dionica i ima manje od 50 zaposlenika i godišnji promet i/ili godišnju ukupnu bilancu koja ne premašuje 10.000 .000 eura, b) poduzeće nije registrirano dulje od pet godina. Ako porezni obveznik ne podliježe registraciji, može se smatrati da razdoblje od pet godina počinje kada poduzeće pokrene svoju poslovnu djelatnost ili za nju podliježe oporezivanju, c) poduzeće nije osnovano spajanjem, d) poduzeće ne posjeduje povezana društva. Države članice mogu propisati odbitak za poklone i donacije dobrotvornim tijelima. Naravno da se mogu odbiti i troškovi amortizacije. 
Dr. sc. Zoran Šinković i Luka Pribisalić: Porez na dobit u kontekstu prava Europske unije Zbornik radova Pravnog fakulteta u Splitu, god. 54, 4/2017., str. 837.- 866.

Člankom 11. predviđene su olakšice za rast i ulaganje (AGI). Za potrebe ovog članka, „osnovica vlasničkog kapitala AGI-ja“ znači razlika između vlasničkog kapitala poreznog obveznika i porezne vrijednosti njegova udjela u kapitalu povezanog društva kako je navedeno u čl. 56. ${ }^{57}$ Iznos jednak utvrđenom prinosu od povećanja osnovice vlasničkog kapitala olakšice za rast i razvoj (AGI) može se odbiti od oporezive osnovice poreznog obveznika. Ako dođe do smanjenja osnovice vlasničkog kapitala AGI-ja, iznos jednak utvrđenom prinosu od smanjenja te osnovice postaje oporeziv. ${ }^{58}$

Člankom 12. predviđene su stavke, koje se ne mogu odbiti a to su: a) raspodjele dobiti i otplate vlasničkog kapitala ili duga, b) $50 \%$ troškova reprezentacije, do iznosa koji ne prelazi [x] \% prihoda u poreznoj godini, c) prijenos zadržane zarade u rezervu koja čini dio vlasničkog kapitala poduzeća, d) porez na dobit poduzeća i slični porezi na dobit, e) mita i ostale nezakonite isplate, f) globe i kazne, uključujući pristojbe na zakašnjela plaćanja, koje određuje javno tijelo zbog kršenja nekog zakona i tako dalje.

Člankom 13. regulirana su pravila o ograničavanju kamata na sljedeći način:

1) Troškovi zaduživanja mogu se odbiti u iznosu kamata ili ostalih oporezivih prihoda od financijske imovine koje je primio porezni obveznik;

2) Prekoračeni troškovi zaduživanja mogu se odbiti u poreznoj godini u kojoj su nastali do najviše $30 \%$ zarade poreznog obveznika prije kamata, poreza i amortizacije (,EBITDA“) ili do iznosa koji nije veći od 3.000 .000 eura, ovisno o tomu što je veće. Za potrebe ovog članka, ako je poreznom obvezniku dopušteno djelovati u korist grupe ili se to od njega zahtijeva, kako je utvrđeno u pravilima

57 Ako porezni obveznik sudjeluje u upravljanju, kontroliranju ili, izravno ili neizravno, kapitalu poreznog neobveznika ili poreznog obveznika koji ne pripada istoj grupi, ta se dva društva smatraju povezanim društvima. Ako iste osobe sudjeluju u upravljanju, kontroliranju ili, izravno ili neizravno, u kapitalu poreznog neobveznika i poreznog neobveznika ili poreznih obveznika koji ne pripadaju istoj grupi, sva se predmetna društva smatraju povezanim društvima. Porezni obveznik smatra se povezanim društvom svoje stalne poslovne jedinice u trećoj zemlji. Porezni neobveznik smatra se povezanim društvom svoje stalne poslovne jedinice u državi članici (čl. 56. st. 1.)

Za potrebe st. 1. primjenjuju se sljedeća pravila: a) sudjelovanje u kontroliranju znači udio koji prelazi $20 \%$ glasačkih prava, b) sudjelovanje u kapitalu znači pravo vlasništva na udio u kapitalu koji prelazi 20 $\%$, c) sudjelovanje u upravljanju znači mogućnost znatnog utjecaja na upravljanje povezanim društvom, d) pojedinac, njegov bračni drug i njegov neposredni predak ili potomak smatraju se jednom osobom.

Kada je riječ o posrednim udjelima, ispunjenje zahtjeva iz toč. a i b ovog stavka određuje se množenjem stopa udjela u svim uzastopnim rangovima. Smatra se da porezni obveznik koji posjeduje više od $50 \%$ glasačkih prava posjeduje $100 \%$ tih prava. Za potrebe čl. 61., ako je riječ o hibridnoj neusklađenosti koja uključuje hibridni subjekt, udio iz toč. a i b prvog podstavka znači udio koji premašuje $50 \%$ glasačkih prava ili pravo vlasništva nad kapitalom u udjelu koji premašuje $50 \%$.

58 Povećanja ili smanjenja osnovice vlasničkog kapitala AGI-ja izračunavaju se za prvih deset poreznih godina primjene pravila ove Smjernice na poreznog obveznika kao razlika između razine osnovice vlasničkog kapitala AGI-ja na kraju relevantne porezne godine i njezine razine prvog dana prve porezne godine primjene pravila ove Smjernice. Nakon prvih deset poreznih godina, polazište za izračun iznosa osnovice vlasničkog kapitala AGI-ja koji se može odbiti od njezine razine na kraju relevantne porezne godine pomiče se svake godine za jednu poreznu godinu. Utvrđeni prinos jednak je prinosu od 10-godišnjih referentnih državnih obveznica zemalja europodručja iz prosinca godine koja prethodi relevantnoj poreznoj godini, kako je objavila Europska središnja banka, uvećano za premiju od dva postotna boda. Primjenjuje se donja granica od dva posto ako je krivulja godišnjeg prinosa negativna. 
o nacionalnim sustavima oporezivanja grupa, cijela se grupa smatra poreznim obveznikom. U tim se okolnostima prekoračeni troškovi zaduživanja i EBITDA izračunavaju za cijelu grupu. Iznos od 3.000.000 eura također se uzima u obzir za cijelu grupu;

3) EBITDA se izračunava tako da se poreznoj osnovici poreznog obveznika dodaju iznosi prekoračenih troškova zaduživanja prilagođeni za iznos poreza, kao i iznosi amortizacije prilagođeni za iznos poreza. Prihodi izuzeti od poreza isključuju se iz EBITDA-e poreznog obveznika;

4) Odstupajući od st. 2., porezni obveznik, koji se smatra samostalnim trgovačkim društvom, ima pravo na cjeloviti odbitak svojih prekoračenih troškova zaduživanja. Samostalno trgovačko društvo, znači porezni obveznik koji nije dio konsolidirane grupe za potrebe financijskog računovodstva i ne posjeduje povezana društva ili stalne poslovne jedinice;

5) Odstupajući od st. 2., prekoračeni troškovi zaduživanja mogu se u cijelosti odbiti ako su nastali zbog: a) zajmova sklopljenih prije (datum političkog sporazuma o ovoj Smjernici), uz iznimku bilo kojih posljedičnih izmjena tih zajmova, b) zajmova upotrijebljenih za financiranje dugoročnih javnih infrastrukturnih projekata ako su nositelj projekta, troškovi zaduživanja, imovina i prihod unutar Unije. Ako se primjenjuje toč. $b$, sav prihod od dugoročnog javnog infrastrukturnog projekta isključuje se iz EBITDA-e poreznog obveznika;

6) Prekoračeni troškovi zaduživanja koji se ne mogu odbiti u određenoj poreznoj godini prenose se bez vremenskog ograničenja;

7) Stavci od 1. do 6. ne primjenjuju se na financijska društva, uključujući ona koja su dio konsolidirane grupe za potrebe financijskog računovodstva. ${ }^{59} 60$

Iz svega navedenoga, dade se zaključiti kako je već rečeno sa stajališta porezne politike CCCTB-om će se znatno poboljšati funkcioniranje jedinstvenog tržišta. Trgovačkim društvima koja posluju preko granica pri izračunu oporezive dobiti u Europskoj uniji pogodovat će jedinstven skup pravila umjesto šarolikosti različitih nacionalnih sustava. Preko sustava ,jedinstvene kontaktne točke“ društva će moći podnositi jednu poreznu prijavu za sve poslovne aktivnosti u Europskoj uniji, te će tako kontaktirati samo s jednom državom članicom umjesto s više poreznih tijela. Konsolidacija će značiti i da se gubici u jednoj državi članici automatski mogu otpisati od dobiti u drugoj, čime se omogućuje jednako postupanje s trgovačkim društvima koja posluju preko granica kao s isključivo domaćim društvima. Drugim riječima, ponovno pokretanje CCCTB-a predviđeno je zbog pružanja odgovora na

59 Naknade dodijeljene dioničaru koji je pojedinac, njegovom bračnom drugu, njegovom neposrednom pretku ili potomku ili dodijeljene povezanom društvu, kako je navedeno u čl. 56., ne smatraju se troškovima koje je moguće odbiti ako takve naknade ne bi bile dodijeljene neovisnoj trećoj strani (čl. 14.).

60 Smjernica još obuhvaća: III. poglavlje regulira Vremenske i količinske odrednice, IV. poglavlje Amortizaciju dugotrajne imovine, V. poglavlje Gubitke, VI. poglavlje Pravila o ulasku i izlasku iz sustava porezne osnovice, VII. poglavlje Odnosi poreznog obveznika i ostalih subjekata, VIII. poglavlje Transakcije između povezanih društava, IX. poglavlje Pravila protiv zlouporabe, X. poglavlje Transparentni subjekti, XI. poglavlje Upravni poslovi i postupci, XII. poglavlje Završne odredbe. 
potrebu povećanja rasta i stvaranja radnih mjesta na unutarnjem tržištu, kao i zbog suzbijanja praksi agresivnog poreznog planiranja.

Ne treba zanemariti ni činjenicu da su zagovornici uvođenja CCCTB-a uvjereni da bi sustav određivanja porezne osnovice poreza na dobit trgovačkih društava i multinacionalnih kompanija, mogao donijeti mnoge pogodnosti među kojima se ističe: 1. smanjenje administrativnih troškova i pojednostavnjenje poreznih postupaka, 2. moguću primjenu jedinstvenih pravila pri izračunu dobiti i gubitka cijele skupine u jedinstvenu konsolidiranu bilancu, 3. povećanje transparentnosti, 4. smanjenje poreznog opterećenja te povećanje učinkovitosti ubiranja poreza, 5 . uklanjanje porezne diskriminacije među državama članicama Europske unije, 6. otklanjanje dvostrukog opterećenja u međunarodnim transakcijama i 7) sprječavanje zlouporabe poreznih propisa u vezi s oporezivanjem takvih subjekata. ${ }^{61}{ }^{62}$

Postoje i argumenti protiv uvođenja konsolidirane zajedničke osnovice poreza na dobit. To se npr. odnosi na sljedeće: 1) uvođenje CCCTB-a uvelike bi se smanjio suverenitet nacionalnih država u pogledu samostalnog stvaranja sustava izravnih poreza, 2) ujednačavanje poreznih osnovica svelo bi poreznu konkurenciju u području oporezivanja dobiti na konkurenciju poreznim stopama, pa bi članice koje se u prikupljanju poreza danas snažno oslanjaju na porez na dobit, morale snižavati stope poreza na dobitak i gubiti dio poreznih prihoda kako bi spriječile seljenje kapitala u druge zemlje, 3) prekogranično konsolidiranje pogodovalo bi velikima, multinacionalnim društvima najčešće sa sjedištem u najrazvijenijim članicama, dok bi manje razvijene mogle pretrpjeti negativne posljedice u prihodu od poreza na dobit, 4) upitno je bi li države članice pristale na široku definiciju osnovice te ukidanje brojnih izuzeća, olakšica i posebnih režima koje danas nacionalne porezne vlasti iskorišćuju kao važan instrument gospodarske politike. ${ }^{63}{ }^{64}$

\section{ZAKLJUČAK}

Oporezivanje je ključno u radu Europske unije na izgradnji snažnijeg, konkurentnijeg i pravednijeg gospodarstva s jasnom socijalnom dimenzijom. Europi je potreban porezni sustav prilagođen njezinu unutarnjem tržištu kojim se podržavaju gospodarski rast i konkurentnost, privlače ulaganja, pomaže otvarati radna mjesta, potiču inovacije i podupire europski socijalni model. Oporezivanjem se trebaju omogućiti stabilni prihodi za javna ulaganja i politike kojima se pogoduje

61 Harmonised corporate and consolidated tax base for companies in Europe? What you should know about the CCCTB«. Dostupno na mrežnoj stranici: http://www.pwc.com/lt/lt/assets/publications/PwCnewsletter-on-CCC-TB-03-2011.pdf.

62 T. Bartoli-Kos, N. Žunić-Kovačević, „Europski projekt uspostave zajedničke osnovice oporezivanja dobiti trgovačkih društava CCCTB“, Porezni vjesnik, br. 12., Ministarstvo financija Porezna uprava Središnji ured, Zagreb, 2012., str. 40-41.

63 Lithuanian Free Market Institute, Harmonisation of the Corporate Tax Base in the European Union, Analytical Study, 30. ožujka 2006., dostupno na mrežnoj stranici: http://www.freema.org.

64 T. Bartoli-Kos, N. Žunić-Kovačević, Europski projekt... o. c., str. 45. 
rastu. Ono bi svim poduzećima trebalo osigurati jednake uvjete, pravnu sigurnost i minimalne prepreke pri prekograničnom poslovanju. Oporezivanje bi trebalo biti dio šireg poreznog sustava u koji građani imaju povjerenje, jer je pravedan i jer ispunjava socio-ekonomske potrebe društva. Stoga su prioriteti Europske unije u oporezivanju usredotočeni na ostvarenje tih ciljeva.

S druge strane u prepreke prekograničnom poslovanju, što nastaju kao posljedica postojanja različitih poreznih režima, prema Grammieu i drugima može se ubrojiti: 1) visoke troškove udovoljavanja poreznoj obvezi (npr. troškovi usluga poreznih savjetnika ili edukacije, radi upoznavanja poreznih propisa), 2) nemogućnost da se u poreznu osnovicu uračuna gubitke nastale u drugim zemljama, 3) dvostruko oporezivanje što nastaje radi primjene propisanih metoda obračuna transfernih cijena pri alokaciji dobitka multinacionalnih kompanija, 4) povećano oporezivanje porezom na kapitalne dobitke ili dvostruko oporezivanje, kada su u pitanju transakcije pri restrukturiranju trgovačkih društava (npr. zakonsko spajanje, podjela, pripajanje trgovačkih društava i sl.) i 5) dvostruko oporezivanje, zbog teškoća u pogledu razgraničenja nadležnosti različitih država za oporezivanje. ${ }^{65}$

Porez na dobit vrlo je važan porezni oblik u kontekstu prava Europske unije. Stoga je doneseno nekoliko Smjernica vezanih za oporezivanje dobiti. Europska komisija 25. listopada 2016. godine donijela je prijedlog Smjernica o zajedničkoj osnovici poreza na dobit (CCCTB). Drugim riječima ponovno pokretanje CCCTB-a predviđeno je zbog pružanja odgovora na potrebu povećanja rasta i stvaranja radnih mjesta na unutarnjem tržištu, kao i zbog suzbijanja praksi agresivnog poreznog planiranja. Svi su ti ciljevi prije svega usmjereni na rješavanje problema izvan okvira pojedine države članice, te je stoga po prirodi potreban zajednički pristup. U tom svjetlu bilo koje mjere mogle bi postići rezultate samo kada bi se pravila primjenjivala na ujednačen način diljem unutarnjeg tržišta. Kada to ne bi bio slučaj, situacija u području oporezivanja dobiti poduzeća ostala bi fragmentirana, čime bi se omogućio razvoj fiskalnih prepreka i praksi nepoštenog natjecanja u području oporezivanja. Europskoj uniji potreban je sustav poreza na dobit osmišljen za potporu konkurentnijoj, inovativnijoj i gospodarski stabilnijoj Europskoj uniji. Rast i ulaganja oslanjaju se na okružje kojim se omogućuje poslovanje, potiče produktivno financiranje, te nagrađuju istraživačke i inovacijske aktivnosti kojima se pogoduje rastu. CCCTB-om će se trgovačkim društvima omogućiti stabilna i predvidljiva pravila, jednaki uvjeti te smanjenje troškova i administracije, zbog čega će Europska unija postati vrlo privlačno tržište za ulaganja. Osim toga, Komisija je prijedlog o CCCTB-u pojačala novim odredbama koje su posebno usredotočene na aktivnosti poticanja rasta.

65 G. Malcolm, S. Giannini, A. Klemm, A. Oestereicher, P. Parascandolo, C. H. Spengel, Achieving a Common Consolidated Corporate Tax Base in the EU, Centre for European Policy Studies, Bruxelles, 2005 . 


\section{CORPORATE TAX IN THE CONTEXT OF THE EUROPEAN UNION LAW}

Corporate tax is a very important tax forms. Therefore, the European Commission adopted Proposal on a Common Corporate Tax Base (CCCTB). The re-launch of the CCCTB initiative aims to facilitate business within the EU by subjecting taxpayers to a single rulebook of corporate tax legislation to apply across the internal market and also make the system more robust and resilient to aggressive tax planning. Both objectives impact decisively and directly on to the internal market, precisely as they aim to eradicate distortions in its functioning.

Keywords: European Union, corporate tax, consolidated tax base 